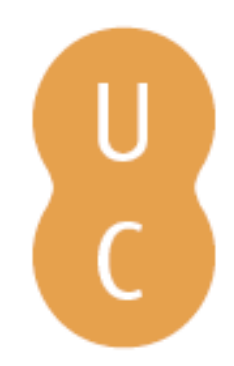

\title{
pompalina
}

\section{Oração em louvor de todas as doutrinas e ciências}
Autor(es):
Fernandes, Pedro
Publicado por: Imprensa da Universidade de Coimbra
URL
persistente:
URI:http://hdl.handle.net/10316.2/30832
DOI:
DOI:http://dx.doi.org/10.14195/978-989-26-0448-0_3

Accessed : $\quad$ 26-Apr-2023 02:36:03

A navegação consulta e descarregamento dos títulos inseridos nas Bibliotecas Digitais UC Digitalis, UC Pombalina e UC Impactum, pressupõem a aceitação plena e sem reservas dos Termos e Condições de Uso destas Bibliotecas Digitais, disponíveis em https://digitalis.uc.pt/pt-pt/termos.

Conforme exposto nos referidos Termos e Condições de Uso, o descarregamento de títulos de acesso restrito requer uma licença válida de autorização devendo o utilizador aceder ao(s) documento(s) a partir de um endereço de IP da instituição detentora da supramencionada licença.

Ao utilizador é apenas permitido o descarregamento para uso pessoal, pelo que o emprego do(s) título(s) descarregado(s) para outro fim, designadamente comercial, carece de autorização do respetivo autor ou editor da obra.

Na medida em que todas as obras da UC Digitalis se encontram protegidas pelo Código do Direito de Autor e Direitos Conexos e demais legislação aplicável, toda a cópia, parcial ou total, deste documento, nos casos em que é legalmente admitida, deverá conter ou fazer-se acompanhar por este aviso.

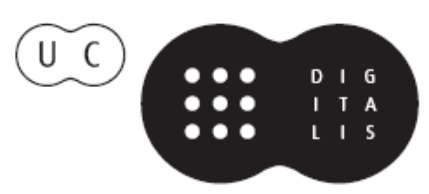




\section{Portvgaliae}

Monvmenta Neolatina

VOL. XI

ORAÇÕES

DE SAPIÊNCIA

$1548-1555$

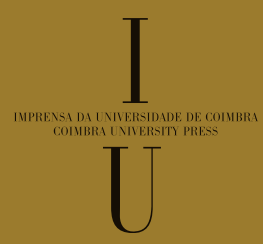




\title{
PEDRO Fernandes
}

\author{
ORAÇÃO \\ EM LOUVOR DE TODAS \\ AS DOUTRINAS E CIENNCIAS \\ 1 de Outubro de 1550
}

Introdução, fixação do texto latino, tradução e notas

Maria Manuela Pereira Pinto Dourado Alvelos

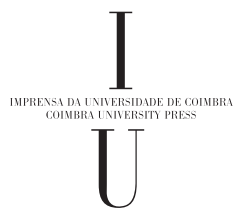


(Página deixada propositadamente em branco) 


\section{IN MEMORIAM}

Em tuas mãos sonhadas, Chico, deponho esta dádiva,

acrisolada no espanto absoluto da tua partida

sem tempo de adeus. 
(Página deixada propositadamente em branco) 


\title{
INTRODUÇÃO
}

\author{
I \\ DADOS BIOGRÁficos
}

\section{Naturalidade e formação}

São escassas as notícias que até nós chegaram acerca de Pedro Fernandes. Deste modo, apesar de havermos percorrido as principais bibliotecas do país, em busca de dados que nos elucidassem sobre a vida e personalidade do humanista, apenas podemos apresentar, a seu respeito, um conjunto de notas biográficas.

Parece estar fora de dúvida que Pedro Fernandes nasceu em Lisboa. De facto, assim o afirmam Diogo Barbosa Machado na Biblioteca Lusitana, tomo III, p. 576; Carneiro de Figueiroa em Memórias da Universidade de Coimbra, p. 78; Leitão Ferreira no Alfabeto dos Lentes da Insigne Universidade de Coimbra, p. 224 e Dr. Luís de Matos em Les Portugais à l'Université de Paris entre 1500 et 1550, p. 98.

Nos documentos por nós consultados, encontrámos uma referência a tal assunto. Assim, na carta de mestre de Pedro Fernandes, passada pela Universidade de Paris e cuja cópia se encontra no Arquivo da Biblioteca Geral da Universidade de Coimbra, lê-se a seguinte afirmação: “... quod dilectus noster discretus uir magister petrus ferdinandus diocesis Ulisiponensis...".

A própria filiação de Pedro Fernandes vem também ajudar-nos a confirmar a sua naturalidade. Seu pai, Francisco Fernandes, era guarda das damas da Infanta D. Maria, irmã de D. João III. Assim nos diz a en Corporação de mestre em artes de $p^{\circ}$. frz, publicada quase integralmente pelo Dr. Mário Brandão nos Documentos de D. João III, vol. IV, p. 52, referindo-se também ao facto Diogo Barbosa Machado, op. cit., p. 576, Carneiro de Figueiroa, op. cit., p. 78 e Leitão Ferreira nas Notícias Cronológicas da Universidade de Coimbra, vol. III, t. I, p. 39. Este último faz uma notória confusão, ao atribuir a Pedro Fernandes a profissão do pai, além da que teve realmente.

Podíamos até ir mais longe e perguntar: não terá Pedro Fernandes nascido na Corte? Relacionemos com esta suposição o documento por nós consultado no Arquivo 
da Biblioteca da Universidade de Coimbra, que diz respeito ao exame $p(e r)^{a}$. brel de $p^{o}$. frz. Aí se diz - "mestre $\mathrm{p}^{\circ}$. frz da Corte...". Unicamente por lá prestar serviços, ou também por lá ter nascido? Talvez por ambos os motivos.

De facto, Pedro Fernandes foi moço de câmara de D. João III, como atestam dois passos da en Corporação de mestre en artes de $p^{\circ}$. frz: " $\mathrm{p}^{\circ}$. frz moço da Camara

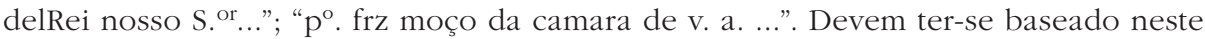
documento, directa ou indirectamente, os autores que confirmam tal profissão. São eles: Diogo Barbosa Machado, Carneiro de Figueiroa e Dr. Luís de Matos, nas obras e páginas já referidas. E Leitão Ferreira no Alfabeto dos Lentes..., p. 224.

A respeito deste cargo, pouco conseguimos saber, a não ser que... D. João III tinha 911 moços de câmara. ${ }^{1}$

\section{Estudante em França}

Em dada altura, Pedro Fernandes ausenta-se da corte e vai frequentar a Universidade de Paris. Em que data? A propósito, diz o Dr. Luís de Matos, op. cit., p. 98: "Pedro Fernandes prêta serment au recteur Ludovicus Charpentier, déc. 1544 - mars 1545 - manusc. lat. 9954, fol. 4 ${ }^{\mathrm{r}}$. Il était arrivé en France avant cette date, car il retournait au Portugal en 1549, au plus tard après avoir étudié le droit canon pendant six ans à l'Université de Paris, et y avoir obtenu sa maîtrise ès-arts".

Dirige-se para essa Universidade como bolseiro do Rei? O Dr. Luís de Matos, na obra e página já referidas, considera que o não deve ter sido, apesar de o humanista, na sua oração de sapiência, afirmar que D. João III "in suorum numero adscribi iussit et cui litterarium otium concessit”. Esta frase, porém, leva-nos a concluir que foi estudar como bolseiro. De resto, Carneiro de Figueiroa, op. cit., p. 78 e Leitão Ferreira, nas Notícias Cronológicas..., vol. III, tom. I, p. 39, afirmam que o Rei "o mandou estudar à Universidade de Paris". Se o mandou, certamente lhe pagava os estudos. Na en Corporação de mestre em artes do humanista, lemos: “... Elle cõ licença de v. a. foi estudar a paris...". Será neste documento que o Dr. Luís de Matos fundamenta a sua afirmação? Na verdade, o emprego do termo licença faz-nos ficar na dúvida. Todavia, parece-nos muito provável que tenha sido bolseiro, até por estar tão ligado à Corte de D. João III.

Quanto à sua permanência na Universidade estrangeira, ele próprio a ela se refere na dedicatória da sua oração de sapiência ao Rei: "Cum in hanc tuam, Rex Inuictissime, florentissimam Academiam e Gallia uenissem...". Não alude concretamente à Universidade de Paris: fala apenas de Gália. Talvez o faça propositadamente, pois parece ter estado também em Tolosa. Assim nos diz um documento - Autos e

${ }^{1}$ Vid. Alfredo Pimenta, D. João III, p. 313: "Tinham moradias na Casa Real, pessoal de D. João III; 5 bispos; 3 capelãis de conselho; 142 capelãis; 124 moços de capela; 52 cantores...; 32 letrados e físicos; ...911 moços de câmara...”. 
Graus, tomo IV, liv. I, pp. 26 v.-27 - que faz referência à estadia do humanista nesta Universidade: “... p(er) q cõstava q o dito $\mathrm{p}^{\circ}$. frz provara $\mathrm{p}(\mathrm{er})$ duas tas. q ouvira seis cursos de Canones en Paris e Tolosa...". Não sabemos até que ponto devemos dar crédito a este documento, pois é a única notícia que temos da possível permanência de Pedro Fernandes em Tolosa. Nos outros documentos e nos autores que ao assunto se referem, apenas é mencionada a frequência na Universidade de Paris.

Do seu estudo nesta Universidade, sabemos somente - através da en Corporação de mestre em artes de $p^{\circ}$. frz, da carta de mestre de $p^{\circ}$. frz, de Autos e Graus, tomo IV, liv. I, pp. 26 v-27 e dos autores e obras referidas - que em 1546 era Mestre em Artes e que, na mesma Universidade, frequentou seis anos de Direito Canónico. O humanista refere-se a essa frequência de vários anos de Direito, quando diz na dedicatória: "Cum in hanc tuam, Rex Inuictissime, florentissimam Academiam e Gallia uenissem, ibique Iuris studia, quibus inde ab aliquot annis eram initiatus, prosequerer...".

Em Paris terá travado conhecimento com António de Cabedo, autor dos três dísticos elegíacos que prefaciam a oração de sapiência. Assim o afirma o Dr. Luís de Matos, op. cit., p. 98: "Pedro Fernandes et António Cabedo se sont sans doute connus à Paris; dans le discours on trouve une composition en vers latins de celui-ci à l'éloge de l'auteur".

\section{Carreira universitária em Coimbra}

Diogo Barbosa Machado, op. cit., tomo I, pp. 226-227, alude a essa permanência em Paris, acrescentando que recebeu "na Universidade de Coimbra as insignias doutoraes em Direito Canonico, em que era muito perito". Como se pode ver em Dr. Mário Brandão, Actas dos Conselhos da Universidade de 1537 a 1557, vol. II, $1^{\text {a }}$ parte, pp. 179, 181 e 194, e vol. II, $2^{\text {a }}$ parte, pp. 184, 187 e 225, e nos Autos e Graus, tomo V, vol. I, f. 50 v., António de Cabedo encontrava-se em Coimbra entre os anos de 1549 e 1554. Concluir-se-á então que o seu regresso se efectuou, o mais tardar, em 1549, pois que aparece a data de 22 de Novembro do mesmo ano na en Corporação de mestre em artes de $p^{\circ}$. frz.

Pedro Fernandes é, na verdade, incorporado na Universidade de Coimbra em 14 de Maio de 1550, onde lhe é dada a correspondência do grau de Mestre em Artes adquirido em Paris e lhe são tomados em conta os seis anos de Jurisprudência Canónica.

E, "ainda que não foi Mestre da Universidade de Coimbra"2, pronuncia neste mesmo ano, em 1 de Outubro, "com admiração de todos os cathedráticos", a Oração

\footnotetext{
${ }^{2}$ Leitão Ferreira, Notícias Cronológicas..., vol. III, tom. I, pp. 42-43, § 89. Pedro Fernandes não foi o único não-professor a proferir uma oração de sapiência. André de Resende não o era em 1534, ano em que também pronunciou a sua oratio pro rostris.
} 
de Sapiência "que dedicou a seu Serenissimo Amo em que se descobre a profunda intelligencia da lingoa Latina, como dos preceitos da Oratoria". ${ }^{3}$

O próprio Pedro Fernandes afirma na dedicatória da oração “... non passi sunt amici, ut in ea [Academia] diutius ignotus uersarer. Rogarunt itaque me, ut orationem illam, quae in doctrinarum scientiarumque omnium commendationem, a maioribus est instituta, Cal. Octobr. haberem".

A oração foi publicada um mês depois de ter sido proferida, o que mostra a importância que, ao tempo, se atribuía às letras clássicas.

Pedro Fernandes só nos reaparece em 8 de Fevereiro de 1556, no seu acto de bacharel em Cânones. Deste acto fala-nos Carneiro de Figueiroa nas Memórias da Universidade de Coimbra, p. 78, neste termos: “... e em 6 de Fevereiro de 1556 se achava outra vez nesta Universidade e pedio ao Conselho o admitissem logo a fazer acto de Bacharel, por quanto El Rey o mandava para a Índia com o Arcebispo de Goa, e com efeito fez o dito Acto em 8 do dito mez".

Percorremos em vão documentos e autores, no sentido de confirmarmos a possível ida de Pedro Fernandes para a Índia. Nenhum alude a este facto. Leitão Ferreira, nas Notícias Cronológicas..., vol. III, tom. I, pp. 42-43, § 89, chega a remeter-nos para o ano de 1556 - "veja-se o ano de 1556". Mas nada há a respeito deste ano. Não terá chegado a publicar o que a ele se referia? É o que concluímos, visto que esse ano devia ser tratado no vol. III, t. III, que não existe.

\section{Viagem à Índia?}

Relacionado com este, surge-nos ainda outro problema: com que arcebispo iria Pedro Fernandes para Goa e em que data? Talvez numa data próxima, pois segundo Carneiro de Figueiroa - o humanista pediu ao Conselho que o admitisse logo a fazer exame de bacharel, para poder seguir para a Índia. Diz o mesmo autor, nas suas Memórias da Universidade de Coimbra, que "do que disse a respeito de Pedro Fernandes, se infere que a Igreja de Goa foi erecta em Metropolitana à instancia de El-Rey D. João o $3 .^{\circ}$ e não de El-Rey D. Sebastião como diz o R. P. D. Antonio Caetano no Cathalogo dos Arcebispos de Goa, pois consta que em Fevereiro de 1556 já havia Arcebispo de Goa que estava para fazer viagem para o seu Arcebispado".

São conformes os dados que nos permitem concluir algo de positivo acerca da data da tomada de posse do primeiro Arcebispo de Goa. Foi ele D. Gaspar de Leão, que tomou posse em Abril de 1560.

\footnotetext{
3 Diogo Barbosa Machado, Biliotheca Lusitana, tomo III, p. 576.
} 
Quanto à elevação da Igreja de Goa a Metropolitana, há alguns autores que se referem, sem exactidão, a Paulo III e ao ano de 1557. Mas quem, na realidade, o fez foi Paulo IV, em 1558.

De qualquer modo, o que concluímos facilmente é que por volta de 1556 não havia Arcebispo de Goa... E isso foi notado a Carneiro de Figueiroa que, em resposta, acrescenta em suplemento à p. 78 das Memórias da Universidade de Coimbra, p. 220: "Do que tenho referido - He sem duvida que nesta monção forão para a Índia o Patriarca João Nunes Barreto, e o Bispo André de Oviedo, e nenhum outro para bispo ou Arcebispo de Goa e tão bem é certo que o imidiato sucessor de Fr. João de Albuquerque que faleceo em 28 de Fevereiro de 1553 foi D. Gaspar que tomou posse em 1560 e foi o primeiro Arcebispo como diz o doutíssimo Academico, mas hé tão bem sem dúvida que o assento do Conselho diz o que tenho referido".

É, portanto, o "Assento do Conselho" que serve de base a Carneiro de Figueiroa. Nada encontrámos no Arquivo da Biblioteca Geral da Universidade de Coimbra que viesse comprovar as afirmações feitas por este autor.

Nada podemos, pois, concluir acerca da possível ida de Pedro Fernandes para Goa. Terá ido de facto? Em que ano? Com que finalidade? Seria um inquisidor? Parece-nos possível esta última hipótese, em face das afirmações de Eugénio Asensio acerca da ida de D. Gaspar de Leão para Goa: “... La armada, arca de Noé de la cultura, passaba à la lejana India las letras, la ciencia y la lengua de Portugal. Transportaba también las instituciones: en la misma nao São Vicente [...] viajaban con D. Gaspar los flamantes inquisidores que iban a implantar el temido tribunal en la colonia invadida de judaizantes...". E, na verdade, aparece-nos um Pedro Fernandes "sollicitador do santo offício", exactamente na mesma época do nosso humanista - 11 de Fevereiro de 1550 - como se lê em Braamcamp Freire, Arquivo Histórico Português, vol. VI, p. 469.

O Conde de Ficalho, na sua obra Garcia de Orta e o seu tempo, pp. 194-195, refere "um mestre Pedro Fernandes" em Goa, por volta de 1546. É uma data demasiado recuada para ter a ver com o nosso humanista.

Achamos pouco provável que Carneiro de Figueiroa tenha confundido o nosso Pedro Fernandes com qualquer outro Pedro Fernandes que tenha ido para Índia, até porque ele próprio nos diz que o "Assento do Conselho" assim o documenta. Mas, por outro lado, não podemos prosseguir no estudo de tal problema, porque os dados nos faltam totalmente.

Dissemos, umas linhas atrás, que Pedro Fernandes, após ter pronunciado a oração de sapiência, só reaparecia em 1556. Será isto exacto? A verdade é que as Actas dos Conselhos da Universidade de 1537 a 1557, publicadas pelo Dr. Mário Brandão, nos apresentam, a pp. 197-200, em 1554 o nome de Pedro Fernandes, nas "Actas da Oposição para lente substituto de uma catedrilha de Cânones". Nas votações lê-se "item $\mathrm{p}^{\circ}$. frz". Parece-nos provável a identificação deste com o nosso humanista, mas, mais uma vez, nada podemos concluir por falta de elementos que façam luz sobre o problema. 


\section{Homonímia e identificação}

O nome de Pedro Fernandes era frequente na época em que viveu o nosso humanista.

Pareceu-nos interessante deixarmos aqui ligeiras referências a alguns dos seus homónimos, até porque, nas investigações que efectuámos para encontrarmos dados biográficos de Pedro Fernandes, nos confrontámos com muitas dificuldades em distinguir, de entre muitos, o humanista em estudo. Referiremos, no entanto, apenas aqueles que, uns mais do que outros, algo se notabilizaram.

A par do "nosso" Pedro Fernandes, há um outro, também natural de Lisboa, elogiado por Pedro Sanches na "Epistola ad Ignatium de Moraes". É "Roderico patre creatum", segundo essa mesma carta, publicada no Corpus Poetarum Lusitanorum, vol. I. Diogo Barbosa Machado, op. cit., tom. III, p. 577, refere-se a ele, deste modo: "Pedro Fernandes, natural de Lisboa, filho de Rodrigo Gonçalves, Jurisconsulto. Estudou na Universidade de Coimbra Direito Civil, sendo insigne Professor de letras humanas, e elegante Poeta latino, cujo idioma ensinou já quando era Eclesiastico aos filhos do Excellentissimo Conde de Vimioso D. Affonso de Portugal. Obteve huma Igreja, onde falleceo no anno de $1569 \mathrm{com}$ saudade das suas ovelhas. Descreveo em verso heroico latino a solemne Procissão do Corpo de Deus, que no anno de 1559 fez a Parochial Igreja de S. Julião de Lisboa, onde fora bautisado e se publicou com este título: De spectaculis D. Juliani Ulyssiponensis in Festo Eucharistiae anno salutis 1559 [...]". O Dr. Luís de Matos, op. cit., p. 98, fala-nos também deste humanista, pressupondo a distinção entre ele e o nosso Pedro Fernandes. De acordo com os resultados atrás apresentados, concluímos ser bastante nítida essa distinção.

Houve um outro Pedro Fernandes - este, natural de Évora - que estudou Humanidades e Teologia em Paris. Foi o primeiro bispo do Brasil - nomeado em 1551 - donde partiu em 1556 em direcção a Lisboa, tendo sofrido, porém, um naufrágio e acabando por ser devorado pelos índios. A ele se referem Diogo Barbosa Machado, op. cit., t. III, pp. 578-579; Fortunato de Almeida, História da Igreja em Portugal, vol. III, parte II, p. 965 e Dr. Luís de Matos, op. cit., p. 54.

Em Lovaina aparecem três Pedros Fernandes - em 1524, 1536 e 1541 - citados pelo Dr. Luís de Matos, op. cit., p. 54. Poderia aventar-se a hipótese de o nosso humanista ser este Pedro Fernandes que, em 1541, se encontrava em Lovaina - não falamos já nos outros, porque as datas são demasiado recuadas. Mas, além de ser filho de Álvaro - "Petrus Ferdinandus filius Alvari Lusitanus" - há a considerar o facto de nenhum documento nem autor se referir consistentemente à permanência de Pedro Fernandes - autor da oração de sapiência - em Lovaina.

Em três documentos dos Autos e Graus, vimos a assinatura dum Pedro Fernandes que concluímos não ser a do nosso humanista, já que num desses documentos se afirma que se trata de Pedro Fernandes, natural de Paranhos, que cursou Teologia entre 1557 e 1560. 
Deparámos ainda com um Pedro Fernandes de Santarém que, em 14 de Julho de 1543, tomou o grau de bacharel em Cânones. E encontrámos outro, de Canas de Senhorim, filho de Francisco Anes, que se matriculou na Universidade em 18 de Dezembro de 1537.

De início, tivemos uma certa dificuldade em distinguir o nosso Pedro Fernandes destes, naturais de Santarém e de Canas de Senhorim, especialmente porque as fichas do Arquivo da Biblioteca Geral da Universidade de Coimbra a eles respeitantes contêm algumas incorrecções. Para os podermos analisar, transcrevemos a seguir as referidas fichas:

PEDRO FERNANDES

Natural de Corte (Lisboa)

Datas de Matrícula:

1 curso de Código, começou em Outubro de 1558 a 5-VI-1559.

Provas de Curso:

1 curso de Instituto - 1-X-1557 a VI 1558

Leis: 1-X-1559 a 6-VI-1560.

Actos e graus:

Exame para Bacharel em Cânones - 8-II-1556. A. Nemin.

Grau de Bacharel em Cânones - 8-II-1556

PEDRO FERNANDES

Filho de Francisco Annes

Nat. de Canas de Senhorim

Fac. Cânones

Datas de matric.

18-XII-1537 - 25-X-1540

Provas de curso:

provou ter ouvido na Universidade de Paris, 6 anos em Cânones.

Actos e graus:

Bacharel em Cânones 14-VIII-1543

recebeu o grau de Mestre em Artes na U. de Paris e foi incorporado na Universidade de Coimbra aos 14-V-1550.

PEDRO FERNANDES

Nat. de Santarém

Fac. Cânones

Provas de curso:

Provou

Actos e graus:

Bach. em Cân. 14-XII-1543

Liv. 3 f. 224 cad. $2^{\circ}$.

Não conseguimos localizar, nos documentos respectivos, o que se diz a respeito do primeiro Pedro Fernandes, a não ser a sua naturalidade e o que é referido nos "Actos e graus", aspectos já anteriormente abordados. É para nós evidente que nesta ficha se estabelece confusão entre o nosso Pedro Fernandes e qualquer outro, como 
fica provado pelas "Datas de matrícula" e "Provas de curso". Pensamos tratar-se de um Pedro Fernandes que tirou o curso de Leis, visto que as cadeiras de Código e Instituto pertencem a esse curso. Assim o afirma Teófilo Braga na sua História da Universidade.

Pedro Fernandes, natural de Canas de Senhorim, é, sem dúvida, uma personalidade distinta de Pedro Fernandes, autor da oração, mas na ficha que lhe diz respeito há confusão com o nosso humanista. Encontrámos o documento que afirma ter sido matriculado em 18 de Dezembro de 1537: "Aos xbiij dias do mês de dz de 1537 anos assentey aquy a $\mathrm{p}^{\circ}$. frz $\mathrm{f}^{\circ}$. de $\mathrm{fr}^{\mathrm{co}}$. anes e de Isabel frz $\mathrm{m}^{\text {or }}$ em Canas de senhom canonista e juravit" (Autos e Provas de Cursos 1537 até 1550, Livro I, cad. 2. ${ }^{\circ}$, f. 165). Todavia, uma vez que obteve o grau de bacharel em Cânones em 14-VII-1543, seria estranho que, após sete anos de o ter recebido, viesse pedir que o incorporassem na Universidade de Coimbra - em Maio de 1550. Aliás, basta consultar o documento dessa incorporação na Universidade de Coimbra, para ficarmos certos de que o que nele se diz não se refere a Pedro Fernandes natural de Canas de Senhorim. Nele se afirma que se trata da incorporação de Pedro Fernandes, filho de Francisco Fernandes, moço de câmara de D. João III, que frequentou em Paris seis anos de Cânones. Logo, o que se diz nesta ficha a respeito de "Provas de curso" e "Actos e graus" é relativo ao nosso humanista e não a Pedro Fernandes de Canas de Senhorim.

Finalmente, temos Pedro Fernandes, natural de Santarém, que, sem dificuldade, concluímos ser diverso do nosso, mas que talvez se vá confundir com o de Canas de Senhorim, na medida em que aparece a data de 14-VII-1543 na ficha de ambos, como data de "bacharel em cânones". Encontrámos, na verdade, essa data referente a Pedro Fernandes de Santarém nos Autos e Provas de Cursos 1537 até 1550, Livro I, cad. $2^{\circ}$., f. 224 v. Transcrevemos um passo do documento que a ela diz respeito: "exame do br $\mathrm{p}^{\circ}$. frs em Canones de Santarem - Em 14 de Julho de 1543 na Universidade de Coimbra $\mathrm{p}^{\circ}$. frs estudante em Canones tomou o grao de br e Canones sob disciplina do doctor martim de spilcueta navarro [...] e tomou o dito grao as seis horas depois do $\mathrm{m}^{\circ}$. dia e p verdade o bedel o esrui."

Como vemos, é pouco o que se sabe ao certo acerca de Pedro Fernandes - autor da oração de sapiência. Tudo fizemos no sentido de reconstituir a sua biografia, mas a escassez de dados obrigou-nos a apresentar, apenas, uma série de problemas, alguns mesmo sem solução. 


\section{A ORAÇÃO DE SAPIÊNCIA}

\section{Conteúdo e composição}

"Em louvor de todas as doutrinas e ciências" - é o título da oração de Pedro Fernandes. Poderá hoje parecer-nos ambicioso, mas, dada a época e as circunstâncias, é apropriado.

Sob este título, o humanista apresenta uma síntese do desenvolvimento e importância que as ciências e os vários campos do saber tiveram na Antiguidade, servindo-se de abundantes citações dos clássicos, que chegam a dar ao seu trabalho um cunho pouco pessoal.

Três dísticos elegíacos da autoria de António de Cabedo prefaciam a oração. Não poderemos dizer que sejam propriamente poéticos. Neles se nota "aquela forçada e martelada elegância dos melhores versejadores latinos da época”. ${ }^{4}$ Quanto ao seu conteúdo, não nos admiremos por neles haver afirmações hiperbólicas. Era habitual, na época, embora hoje nos pareça ousado ver o nome de Pedro Fernandes ao lado dos de Virgílio e Cícero. ${ }^{5}$

Em gesto de gratidão ao Rei Divo Ioanni, Pedro Fernandes dedica-lhe a sua oração. Apresenta o motivo que o levou a proferi-la: era já tempo de mostrar na sua pátria a sua valia intelectual... Para tal, haviam instado os amigos: "Non passi sunt amici, ut in ea diutius ignotus uersarer". O humanista parece ser sincero para com o Rei que, por certo, havia de aceitar esse pequeno trabalho.

Segue-se o texto da oração. No início, Pedro Fernandes aparenta a modéstia que é habitual em todo o orador. Pretende, deste modo, precaver-se contra possíveis críticas, mas deixa entrever que essa modéstia não é sincera, ao dizer que nem mesmo aos grandes vultos foram poupadas críticas.

${ }^{4}$ Vid. Maria Helena da Rocha Pereira, Louvores latinos aos 'Colóquios dos simples e drogas', Porto, Centro de Estudos Humanísticos, 1963, p. 3.

${ }^{5}$ A propósito de elogios hiperbólicos, vid. Maria Helena da Rocha Pereira e Luís de Pina, "Thesaurus Pauperum", Studium Generale, vol. IV, pp. 134 seq. 
Faz, em seguida, uma referência a Deus, criador do Homem, citando, a propósito, um excerto dos Phaenomena de Arato.

E é pelo Homem que vai iniciar a sua exposição. É deveras graciosa a maneira como fala do corpo. Aos olhos chama "fulgida illa sidera", expressão sugestivamente metafórica. Com eles, o Homem pode observar o céu e, consequentemente, observar o movimento dos astros. E assim Pedro Fernandes começa a discorrer sobre a Astronomia, ou seja, inicia o tema com uma certa graça subtil. Não é a única vez que tal acontece. Quase sempre a transição de uma ciência para a outra faz-se com esta subtileza. É, aliás, uma das qualidades que encontramos na sua prosa e com que raramente deparamos nas orações dos outros humanistas.

"Cuius est tanta excellentia..." - diz o nosso autor acerca da Astronomia. E o mesmo dirá das outras artes e ciências...

Faz citações, alonga-se em referências. Mas, como cristão, rejeita a predição do futuro pelos astros, não a desenvolvendo, portanto.

E continuando: se os olhos foram o ponto de partida para a Astronomia, os ouvidos sê-lo-ão para a Música. Não entra na análise da arte dos sons. Refere o prestígio que ela teve na Antiguidade, especialmente grega, recordando casos curiosos, demonstrativos do alto valor pedagógico em que a música era tida entre os antigos.

Este capítulo é especialmente belo pelas referências múltiplas feitas às diversas influências da Música na alma humana.

Mas - continua o nosso orador - se a harmonia musical baila em torno do ouvido, "nec minus circa aures nostras numerus ipse versatur". E, deste modo, entra a considerar a Aritmética, tratando logicamente a seguir, a Geometria. Tal como as outras, "geometriae tamen tanta est excellentia...". É o que procura demonstrar, citando Platão, Pitágoras, Flávio Josefo e outros.

Considera a forma geométrica e faz dela a essência da arte. "Sine geometria non modo haec sed nec rerum omnium speciem et pulchritudinem, quae in partium omnium proportione, uenustaque symmetria posita est posse consistere". Era a concepção clássica da arte do seu tempo: harmonia e beleza.

Mas voltemos ao Homem, diz Pedro Fernandes. E, com aquela não desmentida subtileza, considera o rosto, depois a boca e, claro, surge então a palavra - tradutora de uma ideia - e, por isso, a Gramática! "Videbimus oris effigiem et speciem, Deus bone, quam elegantem, quam utilem, quam necessariam cum ad alia multa, tum maxime ad id, quod animo conceperis explicandum".

A palavra é o meio de expressão da poesia. O humanista entra então em curiosas considerações acerca desta arte.

Pedro Fernandes estima os Poetas. Nota-se neste capítulo um entusiasmo especial, reflectindo, certamente, o sentimento de Cícero no Pro Archia. Assim, afirma: "Poëtas cum dico, absit omnis uerbo inuidia, hominum genus maxime diuinum dico". Exalta a poesia, citando Platão, Crisipo e outros, mas reserva um lugar especial para Moisés, Isaías, Job e Salomão. 
Considerando que a Gramática está na base de qualquer ciência ou arte, transita para a História. Refere a concepção ciceroniana da mesma, citando, textualmente, mais uma vez, as palavras do Arpinate. Curioso ter Pedro Fernandes salientado a sua importância pelo aspecto negativo. Isto é: o homem sem história, sem passado, é "sempre criança".

Válida a razão por que transitou para a Gramática, é também lógica a que faz agora para a Eloquência, da qual afirma: "tanta est excellentia ut eam Sophocles rerum omnium dominam ac Reginam appellet".

Por aproximação de objecto, versa, a seguir, a Dialéctica, em seu entender, essencial para o estudo das demais ciências, em virtude de a mesma discutir o critério de verdade. Diz ainda da sua importância para a Filosofia.

E com a Dialéctica encerra as considerações acerca das Artes Liberais.

Vão seguir-se as Artes que exigem, segundo diz, "altiorem ac profundiorem cognitionem".

Pede benevolência ao auditório e trata, então, da Medicina. É pródigo em citações, apresentando uma ligação bastante perfeita entre os vários aspectos que refere.

Mas, se se louva a Medicina, que trata do corpo, quanto se não deve louvar a ciência que estuda a alma! Estende-se em citações e elogios à Jurisprudência. Deve notar-se que este é um dos capítulos mais extensos.

Dada a gradação apontada, não é de surpreender que "haec omnia, quamuis sint, tamen nescio quid maius, ac diuinius hominum animus, praesertim Christianus requirit... Id autem unum est sacrosancta illa Theologia".

Apressa-se em esclarecer ir tratar da Teologia revelada. A esta reserva uma especial exaltação.

Transita para o Pontificado e Direito Pontifício, com mais síntese, e termina a sua exposição com uma sentença de Énio.

E agora alude, de modo pouco lisonjeiro, à cultura nacional antes de D. João III, certamente para salientar o papel do monarca em prol do desenvolvimento daquela.

Ao louvar o Rei, dirige-lhe aqueles belos versos que Énio dedicou a Rómulo.

Ao Reitor, Diogo de Murça, tece elogios e afirma que referiria o que há a louvar na sua conduta moral, se não o vira presente.

E a concluir, em última vénia, dirige-se novamente ao rei, tendo agora o elogio um tom de epopeia.

Termina, exortando os mestres para que, por eles e neles, se abrigue sempre a ciência naquele templo de Minerva.

Após a leitura da oração, fica-se a pensar quer no teor, quer na originalidade da mesma.

Todo este conspecto das ciências e artes - e não eram muitas, mas eram tudo, então - tem o seu quê de superficial. 
É que propriamente o autor não faz um esforço pessoal de especulação. Cita, transcreve e acabam os outros por falar mais do que ele. Houve, sim, um esforço de síntese. E isso é apreciável, tanto mais que as fontes de informação eram vastas. No entanto, mesmo aqui se põe o problema de Pedro Fernandes ter utilizado obras que facilitaram o seu trabalho, como julgamos ter sucedido com os Antiquarum lectionum libri de Luís Célio.

Afigura-se-nos que a sua cultura não seria muito profunda, pois que frequentemente recorria em segunda mão aos autores clássicos, especialmente gregos.

A sua prosa não é destituída de qualidades. Apresenta, no entanto, aspectos menos positivos.

Há sagacidade na transição dos assuntos - a que já nos referimos várias vezes - mas chega a existir monotonia em expressões laudatórias, que se repetem. À força disso, chega-se ao fim, e quase todas as artes e ciências são tão superiores e excelentes, que não se distinguem numa hierarquia de valores. Só uma faz excepção: a Teologia.

Não lhe faltam rasgos de lirismo. Ténue, mas real. É lírico o panegírico a D. João III, o capítulo dedicado à Música, bem como breves trechos pontuais da oração.

O humanista quase exprime a sua admiração por há mais tempo não ter tido oportunidade de impressionar a Academia. Contudo, perante o Rei mostra-se humilde. Era vulgar esta atitude. Lembremos Camões numa das últimas estrofes d'Os Lusíadas:

Mas eu que falo, humilde, baixo e rudo,

De vós não conhecido nem sonhado?

Da boca dos pequenos sei, contudo,

Que o louvor sai às vezes acabado.

Nem me falta na vida honesto estudo,

Com longa experiência misturado,

Nem engenho, que aqui vereis presente,

Cousas que juntas se acham raramente. ${ }^{6}$

Esta oração - e outras congéneres - é testemunho de uma época de deslumbramento, ansiosa por abarcar todo um mundo intelectual e humano.

O mundo da pátria de Homero e de Virgílio transparece nesta páginas, que se lêem, ainda hoje, com certo enlevo.

${ }^{6}$ Canto X, 154, Os Lusíadas de Luís de Camões - edição nacional, Imprensa Nacional de Lisboa, nova edição revista, Colecções Philae, s.d. Recordemos, de passagem, a distância que se verifica entre a época de D. João III - de euforia à volta de um trono de um rei que foi grande, sem dúvida, sobretudo para a cultura nacional, euforia essa que não deixa de reflectir-se nesta oração - e a de D. Sebastião, a quem Camões dedica o seu poema épico, num tempo de instabilidade e receios, que o poeta tenta afastar com avisos e conselhos que dirige ao Rei nas estrofes finais do poema, prometendo imortalizar o monarca, se os seus feitos forem dignos de uma epopeia. 


\section{Cláusulas métricas}

Pedro Fernandes apresenta neste discurso, de forma sistemática, várias das chamadas cláusulas ciceronianas. Não sabemos se as conhecia ou se o seu ouvido estaria tão habituado à prosa do Arpinate, que as empregava sem disso ter consciência. Aliás, bastava o uso frequente de frases de Cícero para tal acontecer. Eis alguns exemplos dos metros mais utilizados pelo humanista:

Dicoreu $(-\cup \mid-\cup)$ : incitauit; impetrauit; explicandum;

Duplo crético $(-\cup-\mid-\cup-)$ : dicit accedere; cantico pulchrius; firma possesio;

Crético+espondeu $(-\cup-\mid--)$ : eloqui possent; editi simus;

Espondeu+crético $(--\mid-\cup-)$ : possit cognoscere; in primis utile; dignam existimat;

Crético+dispondeu $(-\cup-\mid----)$ : animo mox dicemus; optime fungi possint;

Espondeu+Péon I $(--\mid-\cup \cup \cup)$ : esse crediderit;

Espondeu+tríbraco $(--\cup \cup \cup)$ : non erubuit;

Dispondeu (- - - ): reccurrendum est; terrerentur;

Espondeu+dicoreu $(--\mid-\cup-\cup)$ : conspectum excitauit; ualde gloriosum;

Cláusula heróica $(-\cup \cup \mid--)$ : non dubitaui; incipiendum est.

\section{Edições e manuscritos}

O oração de Pedro Fernandes foi publicada pela primeira vez em Coimbra, no dia 1 de Novembro de 1550, precisamente um mês depois de ter sido pronunciada. Esta primeira publicação foi efectuada nas oficinas dos tipógrafos régios João de Barreira e João Álvares. Atesta-o a própria oração e referem-se ao facto M. P. Lacerda, Bibliografia Lusitana, Manuscrito da Biblioteca Nacional no 7391, p. 576; António Ribeiro dos Santos, "Memória sobre a História da Typografia Portuguesa do séc. XVI", Memórias de Literatura Portuguesa da Academia Real das Ciências de Lisboa, tom. VIII, parte I, p. 80; Diogo Barbosa Machado, Bibioteca Lusitana, tomo III, p. 576.

Desta oração, contactámos com quatro exemplares: um, existente na Biblioteca Pública Municipal do Porto; dois, na Biblioteca Pública Municipal de Évora e ainda, embora só por fotocópia, com o exemplar conservado na Biblioteca Menéndez y Pelayo (Santander). Não tomámos conhecimento da existência de mais exemplares desta edição.

O exemplar da Biblioteca do Porto está contido num volume com capa de couro, que reúne várias outros textos impressos nele encadernados, designadamente uma boa parte das obras do humanista Jorge Coelho e um conjunto de oito composições oratórias da autoria dos humanistas Arnaldo Fabrício, Inácio de Morais, André de Resende, Manuel da Costa, Pedro Fernandes, Hilário Moreira, António Pinto e Melchior (=Belchior) Beleago, cinco das quais integram agora este volume dos Portugaliae Monumenta Neolatina, incluindo precisamente o nosso autor Pedro Fernandes. 
Um dos exemplares da Biblioteca Pública de Évora (RES. 165-166) integra um volume miscelânico bem conservado, em cuja lombada se lê "Petrus / Fernandus / doctrinarum / scientiarum". Nele se conservam, além desta oração de Pedro Fernandes, obras de outros autores em prosa e poesia, como Diogo de Teive, André de Resende, Manuel da Costa.

O outro exemplar da mesma biblioteca eborense pertence ao volume com a cota 2978-2979, encadernado, em capa de carneira restaurada, juntamente com a obra Aurea bymnorum totius anni expositio [...] do padre sevilhano Pedro Núñez Delgado.

O exemplar de Santander faz parte de um livro intitulado Orationes Antiquae Lusitanorum, no qual se incluem oito orações académicas e panegíricas impressas, cinco manuscritos e alguns versos latinos, também manuscritos, "em louvor da Cruz de Cristo". As orações são as mesmas já referidas de Belchior Beleago, Hilário Moreira, André de Resende, Inácio de Morais, Diogo de Teive e a do nosso humanista Pedro Fernandes, e ainda um discurso panegírico de António Luís, bem como a oração de sapiência de Jerónimo de Brito que agora também integra o presente volume (pp. 290-323). ${ }^{7}$

Ao confrontarmos o exemplar da oração de Pedro Fernandes incluído nesta miscelânea de Santander com outros exemplares da mesma edição, vimos que ao primeiro faltam três folhas: as pp. 21-24 e 35-36. Note-se que este exemplar tem uma numeração manuscrita, que é seguida, não acusando essas faltas. Não se trata, portanto, de uma fotocópia incompleta, mas de uma falha que se verifica no próprio exemplar.

Notámos ainda que não faltam cadernos, mas sim folhas soltas. Assim, verificámos que o exemplar da Biblioteca Municipal do Porto consta de três cadernos: dois de oito folhas e um de quarto. O primeiro está assinado com a letra A; o segundo com a letra B e o terceiro com C. No exemplar de Santander, a falta de duas folhas verifica-se no caderno $\mathrm{B}$, após a quinta folha deste; e no caderno $\mathrm{C}$ a falta de uma folha verifica-se após a terceira.

É curioso notar que na página quatro se encontra uma emenda manuscrita de seruire: houve quem achasse que deveria ser seruile, visto que se tinha enumerado uma série de atributos do corpo - infirmus, caducus, mortalis -, e seruile seria mais um que condizia ... Mas não reparou esse alguém que o que se pretende salientar é que o corpo - que é enfermo, caduco, mortal - se fez para servir, e a alma - eterna e imortal - se fez para imperar. Há até um paralelismo de construção bem nítido.

Tomámos contacto com uma edição da oração de Pedro Fernandes promovida por Joaquim de Carvalho nas Notícias Cronológicas da Universidade de Coimbra, vol. III, Tom. II. Esta edição procura reproduzir fielmente o exemplar da Biblioteca Pública Municipal do Porto, apresentando, contudo, alguns erros, como:

\footnotetext{
7 Serviram-nos de fonte para tais informações uma nota do Dr. Costa Pimpão no seu Compêndio de Literatura Portuguesa e um artigo de Miguel Artigas na Revista se História, vol. $\mathrm{X}, 1921$
} 
a) troca do $\mathbf{s}$ e do p pelo f, em: "fagax" (pág. 1019, lin. 12), em vez de "sagax"; "differendi" (pág. 1031, lin. 29), em vez de "disserendi"; "defyderari" (pág. 1032, lin. 15), em vez de "desyderari"; "coefistis" (pág. 1032, lin. lin. 16), em vez de "coepistis";

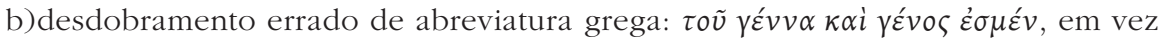
de $\tau$ ov $\gamma \dot{\alpha} \rho$ [...] (pág. 1019, lin. 32);

c) escrita de "haustum" em vez de "haustam" (pág. 1015, lin. 12); "illo" por "illos" (pág. 1023, lin. 13); "suspiciendo" em vez de "suscipiendo" (pág. 1018, lin. 5); d)omissão de "haec", após "non modo" (pág. 1027, lin. 28).

O único manuscrito que enontrámos da oração de Pedro Fernandes pertence à Biblioteca Pública de Évora ( $\operatorname{cod}$. CX/1-4) e é uma cópia do texto impresso, passada pela mão de José Lopes de Mira, como se afirma no Catálogo dos Manuscritos da Biblioteca Pública Eborense, vol. IV. O impresso a que se refere este Catálogo é, sem dúvida, o da primeira edição. Este facto nota-se mesmo em alguns erros que observámos no dito manuscrito.

Assim, várias vezes o copista omite uma linha do referido impresso, levado pela repetição duma palavra que nele se encontra na mesma direcção em duas linhas seguidas, pelo fenómeno chamado homeoteleuto. Por exemplo:

$1^{a}$ edição: "Vnde nostro quodam iure Socraticum illud, quod/ supra nos nihil ad nos, possumus contemnere. Sic e/- nim nihil ad nos coelum ipsum, nihil denique lux ip/ sa pertineat ..."

Manuscrito: "Vnde nostro quodam iure Socraticum illud, quod supra nihil ad nos coelum ipsum, nihil denique lux ipsa pertineat ..."

$1^{a}$ edição: "Semper enim uobis iuuenis est animus, in quo nulla ex uetustatis commemoratione prisca opinio, nulla cana scientia est."

Manuscrito: "Semper enim uobis iuuenis est animus, in quo nulla cana scientia est."

Os erros apresentados pelo manuscrito são, na sua maior parte, de ordem gráfica. Denotam que o copista era distraído e pouco conhecedor da língua latina. Além da já citada omissão de palavras por erro de visão, podemos notar que:

a) elimina quase por completo as geminadas (ex.: "admitebant", "falaces", "supelectilem"); outras vezes faz o contrário (ex.: "obnubilla");

b)acrescenta, suprime e substitui desinências (ex.: "excusationem recusaui"; "uniuersum terrarum orbe_..."; "exercitum omne_..."; "eius nomine tertio"; "[Dialectica] haec certe unam ..."

Este manuscrito pertence a uma miscelânea que contém outras obras, igualmente manuscritas, de diferentes épocas, géneros e autores como Álvaro Gomes e seu irmão Pedro Fernandes Sardinha, primeiro bispo do Brasil, Erasmo, Diogo Pacheco, embaixador de Portugal ao Papa em 1505, e de oradores já referidos em colectâneas anteriores, como Belchior Beleago, André de Resende e o nosso Pedro Fernandes. 
O texto que vamos utilizar na presente publicação é, logicamente, o da edição prínceps, não só porque é ela a única da responsabilidade e da vontade do autor, mas porque a edição e manuscritos posteriores nela se baseiam e lhe introduziram incorrecções.

Maria Manuela Pereira Pinto Dourado Alvelos 
TEXTO E TRADUÇÃO 
PETRI FERDINANDI

\title{
IN DOCTRINARVM \\ SCIENTIARVMQVE OMNIVM COMMENDATIONEM ORATIO
}

\author{
Apud uniuersam \\ Conimbricam Academiam habita \\ Calen. Octobr. Anno M.D.L. \\ AD INVICTISSIMVM \\ Ioannem tertium Portugaliae Regem
}

CONIMBRICAE

Excudebant Ioannes Barrerius et Ioannes Aluarus

Typographi Regii 


\title{
PEDRO FERNANDES
}

\section{ORAÇÃO \\ EM LOUVOR DE TODAS \\ AS DOUTRINAS E CIÊNCIAS}

\author{
Proferida perante \\ toda a Academia de Coimbra \\ em 1 de Outubro de 1550
}

Ao Invictíssimo D. João III

Rei de Portugal

COIMBRA

Imprimiram João de Barreira e João Álvares

Tipógrafos Régios 


\section{Antonivs CaBedivs}

\section{Lectori}

Nunc primum eloquio Musas, nunc denique mixtum Vergilium magno cum Cicerone uides?

Et quondam Aonio doctae post fulmina linguae, Silius Ausonium perluit imbre forum.

Doctas ergo animas et saecula nostra sub uno

Pectore uiderunt delituisse duas. 


\section{ANTÓNIO DE CABEDO}

\section{Ao leitor}

Vês, nesta oração, as Musas primeiro, e depois

Virgílio aliado ao grande Cícero?

Já outrora, após os fulgores da douta língua, Sílio

Banhou o fórum ausónio com as águas da Aónia.

Pois bem, os nossos tempos viram escondidas,

Abrigadas num só peito duas almas sábias. ${ }^{1}$ 
$[3]$

\author{
INVICTISSIMO AVGVSTISSIMOQVE \\ Divo Ioanni, Eivs Nominis Tertio, Lvsitaniae Regi \\ Petrvg Ferdinandvs, Salvtem
}

Cum in hanc tuam, Rex Inuictissime, florentissimam Academiam, e Gallia uenissem, ibique Iuris studia, quibus iam inde ab aliquot annis eram initiatus, prosequerer, non passi sunt amici ut in ea diutius ignotus uersarer. Rogarunt itaque me, ut orationem illam, quae in doctrinarum scientiarumque omnium commendationem a maioribus est instituta, Calendis Octobribus haberem.

Ego uero, ut parum rerum harum ambitiosus et qui semper existimaui melius multo esse bene latere, quam inepte in uulgus prodire, et seueriorum studiorum, quae eloquentem neminem esse patiuntur, et aliarum rerum honesta, ut mihi quidem uidebatur, excusatione recusaui. Quam illi non solum non admittebant, sed (ut fere sunt humana ingenia ad ea quae negantur auidiora) multo uehementius instabant. Itaque, cum diutius denegare, aut ineptum id, aut certe inhumanum uideretur, suscepi tandem munus istud, ut honestissimum ita ualde periculosum.

Quod cum praeter meam expectationem uiderem non solum ab omnibus laudari, sed etiam uehementius expeti, coactus sum id etiam eorum oculis subiicere, quorum auribus uidebam ualde fuisse approbatum.

Quamuis aurium et oculorum iudicium, sciam ualde esse diuersum, multaque nos magis, ut M. Fabius inquit, audita, quam lecta delectare. Tantumque actionem posse, ut etiam his impetret aures, quibus nullus sit in bibliothecis locus. Hoc autem nostrum munusculum tibi, Rex Inuictissime, potissimum offerre multis de causis sum ausus. Tum quia meorum studiorum fructum non apud alium uolui extare, quam apud eum qui me iam inde a puero in suorum numerum adscribi iussit, et cui litterarium otium concessit. [4]Tum etiam quod orationem de doctrinarum omnium excellentia non nisi ei potui offerre qui harum rerum omnium unus et inceptor extitit et perfector; et qui doctrinarum iam paene sepultam cognitionem ab inferis 
[3]

\author{
AO InVictíssimo E Augustíssimo \\ Divino Jỗo, Rei da LusitÂnia, TERCEIRO do SEU Nome, \\ Pedro FERnANdes Apresenta SAUdaçÕes
}

Rei invictíssimo, como eu tivesse vindo da Gália para esta vossa florescentíssima Academia e aí prosseguisse os estudos de Direito, nos quais já há alguns anos me havia iniciado, não suportaram meus amigos que nela, por mais tempo, eu permanecesse ignorado. E me pediram então que proferisse, no dia 1 de Outubro, aquela oração - em louvor de todas as doutrinas e ciências - que pelos nossos maiores foi instituída.

No entanto, sendo eu pouco ambicioso por situações como esta e porque sempre considerei ser muito melhor permanecer bem ignorado, do que aparecer em público de modo inadequado, pedi escusa com a honesta desculpa - na verdade ela assim me parecia - não apenas de estudos mais severos, que não permitem que ninguém seja eloquente, mas também de outras razões. Eles, porém, não só não admitiam essas desculpas, como - porque o engenho humano ordinariamente é mais ávido em relação àquilo que se nega - instavam com mais veemência ainda. E assim, como recusar por mais tempo parecesse quer importuno quer mesmo indelicado, tomei finalmente este encargo tão extremamente honroso quão arriscado.

Ao ver que, para além da minha expectativa, era elogiado por todos e até vivamente exaltado, senti-me impelido a submeter também este trabalho aos olhos de quem eu sabia tê-lo vigorosamente aprovado pelos ouvidos.

Embora eu saiba que o juízo dos ouvidos e o dos olhos são muito diversos e, como diz Marco Fábio, o que se ouve deleita-nos mais do que o que se lê, embora eu saiba que a acção é tão convincente, que consegue criar interesse por aquelas obras a que não daríamos um lugar nas bibliotecas, ${ }^{2}$ todavia, Rei Invictíssimo, a vós de preferência ousei oferecer este nosso modesto trabalho, por várias razões: primeiro, porque não quis apresentar o fruto dos meus estudos junto de outrem, senão junto de quem, desde a minha infância, ordenou eu fosse incluído no número dos seus ${ }^{3}$ e me concedeu o ócio das letras; [4] e ainda porque não podia dedicar esta oração acerca da excelência de todas as doutrinas, senão àquele que foi o único que impulsionou e aperfeiçoou a cultura de todos elas, e que de certo modo fez 
quodam modo excitauit, barbariem expulit, et humanitatem omnem quasi e caelo detractam in domos induxit.

Quare mihi pertimescendum non est, ne haec ut exigua contemnas. Inest enim et sua gratia paruis; et multa uidemus non ob aliud laudari, quam quia parua. Praeterea regium magis nil est, quam id, quod tu soles semper facere, parua libenter accipere, et maxima multo dare lubentius.

Accipe igitur, Rex Augustissime, nostrum hoc munusculum tuo diuino nomini consecratum, eo animo quo aiunt Artaxerxem illum Persarum regem aquam a rustico, utraque manu haustam e proximo fonte oblatam suscepisse.

Quod tanto spero confidentius, quanto certius est te, ut nec augustius, ita nec melius, nec humanius quidquam, uniuersum terrarum orbem non modo non uidisse, sed ne sperare quidem, aut cogitare potuisse.

Vale, felicissime Rex, semper Auguste, Deumque Optimum Maximum oro ut hanc tuam excellentem maiestatem cum hac tua mente beneficentissima diutissime conseruet.

Conimbricae, Calen. Nouemb. Anno M.D.L. 
ressurgir das profundezas o estudo das doutrinas, já quase sepulto, baniu a barbárie e abriu as portas a toda a cultura, como que trazida do céu. ${ }^{4}$

Pelo que não temo que desprezeis este trabalho, por modesto. O que é modesto tem também o seu encanto, e outras razões não vemos por que se louvem, senão pelo facto de o serem. De resto, nada é mais digno de um Rei do que fazer o que sempre Vós costumais: aceitar de bom grado as coisas pequenas, e muito mais de bom grado conceder as maiores.

Aceitai, pois, Rei Augustíssimo, este nosso minúsculo trabalho, dedicado ao vosso divino nome, com aquele mesmo sentimento que, dizem, experimentou o famoso Artaxerxes, rei dos Persas, ao aceitar a água oferecida por um camponês, retirada com ambas as mãos de um rio próximo. ${ }^{5}$

E tanto mais confiadamente espero isto de Vós, quanto mais certo é que toda a terra não viu nem pôde esperar ou conceber nada mais augusto, excelente e erudito que Vós.

Desejo-Vos saúde, felicíssimo Rei, para sempre augusto, e peço a Deus Óptimo Máximo ${ }^{6}$ que conserve por muito e muito tempo essa Vossa Excelsa Majestade aliada ao vosso espírito beneficentíssimo.

Coimbra, 1 de Novembro de 1550. 
$[5]$

\author{
PETRI FERDINANDI \\ In DOCTRINARVM OMNIVM COMMENDATIONEM \\ OrATIO
}

Maxime uellem, Rector amplissime, Patres sapientissimi, Auditores humanissimi, ut mihi hodierno die, hoc grauissimo onere suscepto, tantum ad illud perferendum uirium et industriae adesset, quantum fortasse tunc in suscipiendo superauit audacia.

Verum euenire id multo aliter intelligo; nam uires ipse meas et industriam requirens, animi, quam semel concepi confidentiam nunquam deponendam existimaui.

Quam ut magis retineam, non me mouet excellens aliqua uis ingenii, non frequens aliquis dicendi usus et exercitatio, non denique, quod in his locis plurimum potest, summa auctoritas et amplitudo; sed frequens uester hic consessus conspectusque iucundissimus, tum locus hic ad dicendum et amplissimus et ornatissimus, cuius multo ante praesaga mens mea, ut ultro oblatum grauissimum istud munus non recusarem, et admonuit et incitauit.

Nec illa mihi pertimescenda putaui, quae optimum quemque possent a suscipiendo munere deterrere.

Primum quod ipse priuatus homo, nulla fere auctoritate praeditus, ingenio ualde mediocri, usu [6] ac dicendi exercitatione ea quam et breuissimae temporis angustiae concesserunt; et quam is qui iam ab aliquot annis in Bartolo et Baldo ceterisque huiusce loci atque ordinis hominibus uersatus, potuit retinere; in eum locum de re grauissima dicturus conscendam unde hi dicere consueuerunt, quorum maximae auctoritati summa in dicendo grauitas, cum singulari ubertate, facultate, uarietate, copiaque coniuncta esset; et qui tantum temporis his studiis impertiri potuerunt, quantum ipsi uoluerunt. Quorum orationes cum aures uestras non sint praeteruectae, sed in uestrum omnium animis penitus insederint, et ex earum recordatione plus uoluptatis, quam non modo ex mea, sed ex cuiusquam oratione capere possitis, difficilior mihi hic ad dicendum locus relictus est. 
$[5]$

\author{
ORAÇÃO \\ DE PEDRO FERNANDES \\ EM LOUVOR DE TODAS AS DOUTRINAS
}

Desejaria vivamente, Magnífico Reitor, sapientíssimos lentes, cultíssimos ouvintes, que, no dia de hoje, uma vez que assumi este pesadíssimo encargo, não me faltassem tanto as forças e a indústria para o levar ao fim, quanto, ao aceitá-lo, superou, porventura, a audácia.

No entanto, eu sei que isto se passará dum modo muito diferente: com efeito, ao recorrer às minhas próprias forças e indústria, considerei que nunca devia abandonar a segurança de espírito, uma vez adquirida.

E para que a conserve mais e mais, não me move qualquer notável força de talento, nem um frequente uso e prática de falar, nem enfim - o que nestes lugares pode muito - uma suma autoridade e prestígio, mas antes esta numerosa assembleia e a vossa feliz presença, além deste lugar magnífico e distintíssimo para discursar. E a minha mente, que muito antes previu estas razões, advertiu-me e incitou-me a que não recusasse a espontânea proposta desta pesadíssima tarefa.

Julguei então que não devia recear em demasia aquelas circunstâncias que poderiam desviar qualquer dentre os melhores de assumir um encargo.

Em primeiro lugar, o facto de eu próprio, um simples particular, dotado de quase nenhuma autoridade, com um talento bem modesto, com aquela prática [6] e exercício de falar que as brevíssimas limitações do tempo me concederam, prática essa que pôde adquirir quem já desde há vários anos estudou Bártolo e Baldo e os restantes homens desta posição e classe; sim, o facto de eu subir a este lugar, a fim de falar de assunto tão grave, lugar esse donde se acostumaram a discursar aqueles a cuja máxima autoridade se aliava uma suprema gravidade de expressão juntamente com uma singular facúndia, talento, variedade e riqueza. Esses puderam conceder a estes estudos tanto tempo, quanto eles próprios quiseram. Como as suas orações não tocaram ao de leve os vossos ouvidos, mas antes penetraram profundamente no espírito de todos vós, e como, ao recordá-las, podeis colher delas mais prazer do que da minha ou mesmo de uma oração de qualquer outro, coube-me a mim o lugar mais difícil para aqui discursar. ${ }^{7}$ 
Tum denique quod uarium illud et multiplex hominum ingenium et ancipitem iudiciorum aleam subire, quam sit pertimescendum nemo est qui ignoret.

Cum praesertim quorundam, et eorum quidem nihil aut parum intelligentium, usque adeo barbarum et arrogans sit ingenium, ut nil quamuis perfectum non cauillentur et condemnent; ut fere sunt praeclara omnia ad cauillandum, quam ad aemulandum promptiora. Apud quos non modo ignoscendi spes nulla est, sed ne cognoscendi quidem admittunt consuetudinem.

Quod illi tanto magis suo quodam iure sibi licere existimant, quanto minus uident summos illos oratores, et qui suis praeclaris [7] monumentis non solum ipsi sibi, sed etiam aliis immortale nomen pepererunt, sese ab inuidorum calumniis et obtrectatione potuisse liberare.

Siquidem et lumen illud Graecae eloquentiae Demosthenes, quem admirari quidem potuerunt omnes, imitari nemo, M. Tullius nec satis perfectus uidetur, et interdum dormitare existimatur. Quid? Quidem et ipse M. Tullius excellenti uir ingenio et Romanae facundiae facile princeps, nec M. Bruto, nec Caluo, nec utrique Asinio satis approbatur; sed a quibusdam ut redundans et Asianus, ab aliis uero ut aridus et ieiunus notatur.

At uero Periclem illum, quem et tonare et fulminare et miscere Graeciam uniuersam, et in cuius ore Suadelam quandam Deam insedisse uetus Comoedia praedicabat, sui temporis homines nec elegantem eum, nec satis Atticum putarunt. Iam denique Theophrastum illum, cuius eloquentiam non uulgarem, aut humanam aliquam fuisse nomen ipsum satis ostendit, nonne a decrepita anicula uidemus ut hospitem notatum?

Haec igitur, auditores humanissimi, etsi uiderem satis magna esse, ut optimum quemque possent non solum a suscipiendo hoc munere deterrere, sed etiam ab incepto iam opere retardare, ipse tamen honestissimum hunc laborem subire tandem non dubitaui.

Quod certe facio nulla gloria cupiditate elatus, nulla aut ingenii, aut doctrinae [8] persuasione inductus (scio enim quam id sit temerarium et ab hoc loco debeat esse alienum), sed magis fide ac sapientia uestra confisus, nec tam perficiendi spe, quam obsequendi studio hoc, quicquid est, suscepi.

Rogabat enim is qui suo quodam in me iure proterat imperare, et cui ego non parere sine summo scelere non poteram.

Accedebat etiam honestissimorum hominum meique amantissimorum frequens adhortatio; quorum ego auctoritatem tanto magis admittendam putabam, quanto magis illi singularem uestram humanitatem erant experti. Itaque Spartam hanc ultro delatam, etsi uideam satis a nobis pro dignitate ornari non posse, suscepimus tamen, quoniam honeste a nobis abiicere non potuimus.

Quapropter uos oro atque obsecro, auditores humanissimi, ut me de re, quamuis uobis ualde nota, grauissima tamen dicentem, attente bonaque 
Depois, enfim, porque não há quem ignore quanto é de temer o sujeitar-se à multíplice e vária natureza dos homens e à dúbia sorte dos juízos.

Sendo o carácter de alguns, e principalmente daqueles que pouco ou nada entendem destes assuntos, de tal forma inculto e arrogante, que nada há, por mais perfeito que seja, que não censurem e condenem, naturalmente quase todas as obras notáveis são mais susceptíveis de censura que de imitação. Junto desses não só não há nenhuma esperança de desculpa, como nem admitem sequer o hábito do conhecimento. E por seu próprio direito tanto mais julgam ter valor, quanto menos vêem que os mais notáveis oradores puderam libertar-se [7] por si mesmos das calúnias e invejas dos seus detractores, ao lograrem, através dos seus preclaros monumentos, um nome imortal para si e para os outros.

Assim, Demóstenes, aquele luzeiro da eloquência grega que todos puderam admirar e ninguém imitar, nem por Marco Túlio é considerado assaz perfeito, parecendo-lhe mesmo que por vezes ele dormita. Mas quê? O próprio Marco Túlio, homem de excelente engenho e, sem favor, o príncipe da eloquência romana, não é suficientemente reconhecido nem por Marco Bruto, nem por Calvo, nem por ambos os Asínios, e por alguns chega a ser considerado como redundante e asiano, por outros, como árido e vazio. ${ }^{8}$

Quanto ao famoso Péricles, a respeito de quem a Comédia antiga dizia que ele troava, fulminava e perturbava toda a Grécia $^{9}$ e que nos seus lábios tomara assento uma tal deusa chamada Persuasão, ${ }^{10}$ os homens do seu tempo não o julgaram elegante nem suficientemente ático. Enfim, o notável Teofrasto, cujo nome mostra bem ter tido uma eloquência não vulgar ou humana, não o vemos, porventura, considerado estrangeiro por uma velhinha decrépita? ${ }^{11}$

E assim, cultíssimos ouvintes, embora eu visse que estes exemplos são tão convincentes que poderiam não só desviar o melhor dos homens de assumir este encargo, mas até impedi-lo de continuar a obra já começada, não hesitei todavia em encarregar-me finalmente de tão honroso trabalho. Faço-o, certamente, levado não por algum desejo de glória ou induzido [8] por uma persuasão de talento ou de cultura ${ }^{12}$ (pois sei quanto isso é temerário e deve ser alheio a este lugar), mas, confiado mais na vossa boa-vontade e sabedoria, não tanto na esperança de realizar uma obra perfeita, como com o desejo de ser amável, aceitei este encargo, tenha ele o resultado que tiver.

Rogava-me, pois, aquele que, com um especial direito sobre mim, podia impor as suas ordens e a quem eu não podia deixar de obedecer sem a maior das afrontas. Acrescia também a frequente exortação de homens respeitabilíssimos e meus amigos, cuja autoridade eu considerava que devia ser tanto mais aceite, quanto mais eles reconheciam a vossa singular cultura. E assim, embora eu veja que este encargo, ${ }^{13}$ confiado espontaneamente, não pode ser prestado por nós com a dignidade que merece, aceitámo-lo todavia, pois não poderíamos honestamente enjeitá-lo.

Eis porque vos peço e rogo, ilustres ouvintes, que com atenção e benevolência me ouçais falar acerca de um assunto que, apesar de vos ser muito familiar, é, 
cum uenia audiatis, memineritisque ueteris sapientum hominum prouerbii,

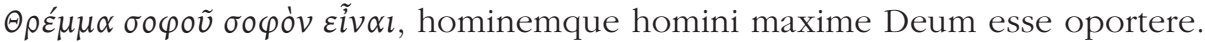
Quod facietis, si fides sapientiaque uestra nostram in dicendo adiuuet industriam. Quod etsi nec oratio mea, nec rei, de qua agitur, dignitas et amplitudo poterit obtinere, ipsa tamen uestra singularis humanitas a uobis facile impetrabit.

De doctrinarum igitur omnium excellentia, cognitioneque dicturi, non aliud quodquam ex omnibus hic animantium generibus, quae sub caelo sunt, [9] proponendum putaui, quam hominem ipsum. Siquidem et hunc solum ex omnibus his, quae uiuunt, doctrinarum scientiarumque omnium participem et cupidum esse, in nobis ipsis et uidemus et experimur.

Verum quoniam homo hic non ex sese ortus est, sed Dei Optimi Maximi opus est et factura,

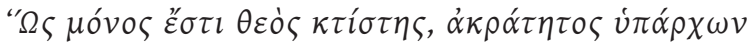

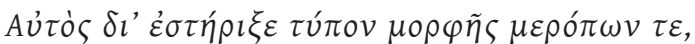

a praepotenti Deo nobis incipiendum est. Quod cum et Christiana doceat religio, tum etiam ille diuino carmine

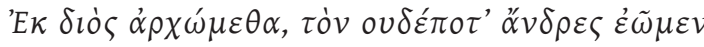

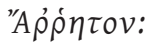

semper his faciendum esse satis admonuit, qui Deum propitium cupiant, et iratum metuant.

Deus igitur Optimus Maximus animal hoc prouidum sagax, multiplex, acutum, memor, plenum rationis atque consilii, quem uocamus hominem, cum procreasset, praeclara eum quadam excellentique condicione procreauit. Quem cum perfectissimum esse uellet, non solum corpore, sed etiam animo constituit, illud infirmum, caducum, mortale seruire, hunc sempiternum, immortalem, diuinum denique uoluit imperare.

Quod qui cognoscit, nonne hominem ipsum satis cognoscit? Quod quidem praeceptum tantum tamque difficile semper fuit, ut id ueteres sapientes non ab homine aliquo, sed ab Apolline Pythio profectum esse existimauerint.

Nec enim is quisquam est, quem aut forma ista demonstrat, aut figura ea quae digito notari potest, sed maiori quadam sapientia [10] opus est, ut quisque nostrum, quid tandem ipse sit, possit cognoscere. Quod certe faciet, si se ipse aliquando circumspexerit, et ad quid natus educatusque sit, satis intelligat. Videbit enim ingenium multo excellentius, quam ut hisce terrenis et fluidis diutius consenescat; quae tanto magis contemnet, quanto magis Deum cognoscet, quem adorabit et contemplabitur, cui se sciet non solum affinitate, sed etiam genere coniunctum; quod et ille intrepide affirmauit:

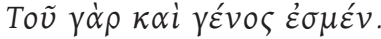

Sed de animo mox dicemus.

Nunc si ipsius corporis statum, si uultum cum summo illo rerum omnium parente communem diligentius inspexerimus, uidebimus hominem, quasi porrecta a Deo manu, e terra alleuatum, ad ipsius contemplationem excitatum. 
contudo, da maior importância ${ }^{14}$ e que vos lembreis daquele velho provérbio dos

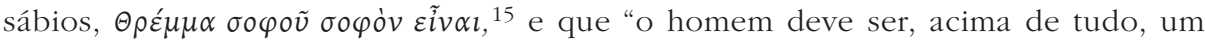
deus para o homem". ${ }^{16}$ Fá-lo-eis, se a vossa boa-vontade e sabedoria vier em auxílio da nossa faculdade oratória. ${ }^{17} \mathrm{E}$ se bem que nem a minha oração nem a dignidade e importância do assunto de que se trata possam consegui-lo, no entanto a vossa singular benevolência obtê-lo-á facilmente de vós próprios.

Pensei então que devia propor-me falar a respeito da excelência e estudo de todas as doutrinas - não outra coisa qualquer dentre todos os seres animados [9] que aqui vivem sob o céu, mas o próprio homem. Na verdade, em nós mesmos vemos e experimentamos que, de todos os viventes, é ele o único que participa e se dedica a todos os ramos do saber e das ciências. ${ }^{18}$

Visto que o homem não nasceu de si próprio, mas é obra e criatura de Deus Óptimo Máximo,

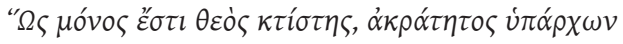

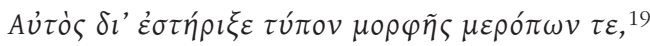

devemos começar por Deus todo-poderoso. ${ }^{20}$ E não só a Religião Cristã dá este ensinamento, como até aquele notável poeta no seu divino carme

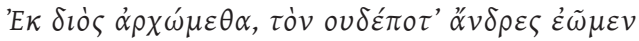

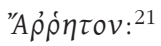

advertiu bem aos que desejam um Deus propício e temem um Deus colérico, de que se devia agir sempre assim.

Ora, pois, este animal previdente, sagaz, multíplice, arguto, cheio de memória, razão e senso, a que chamamos homem, foi criado por Deus Óptimo Máximo, que lhe deu uma natureza preclara e excelente. ${ }^{22}$ E como Ele o desejasse perfeitíssimo, constituiu-o, não só com corpo, mas também com alma e quis que aquele, enfermo, caduco, ${ }^{23}$ mortal, obedecesse, e esta, eterna, imortal, enfim divina, imperasse.

Quem isto conhece, porventura não conhece suficientemente o próprio homem? Este ensinamento foi sempre tão importante e tão difícil, que os sábios antigos o julgaram dimanado não de qualquer homem, mas de Apolo Pítio. ${ }^{24}$

Com efeito, não é ninguém aquele que ou é designado por esta forma ou por aquela figura que pode ser apontada com o dedo; 25 mas é necessário que, com uma sabedoria verdadeiramente superior, $[\mathbf{1 0}]$ cada um de nós possa conhecer enfim o que realmente é. ${ }^{26}$ E consegui-lo-á com certeza, se, de vez em quando, se observar a si próprio, a fim de compreender bem para que nasceu e se instruiu. Verá então uma natureza excelente de mais para que possa envelhecer rodeado destas coisas terrenas e transitórias; e tanto mais as desprezará, quanto mais conhecer a Deus, a quem adorará e contemplará; a Ele se reconhecerá unido, não só pela afinidade, mas até pela natureza, como também aquele poeta famoso intrepidamente o afirmou:

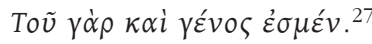

Mas falaremos dentro em pouco da alma.

Agora, se repararmos mais cuidadosamente na posição do próprio corpo, e no rosto, partícipe do pai supremo de todas as coisas, veremos que Deus como que lhe estendeu a mão, para o erguer da terra e o despertar para a Sua contemplação. ${ }^{28}$ 
Corpus enim ipsum non qualecumque, sed erectum et sublime, formaque ipsa et elegantia speciosum efformauit; cui sensus comites attribuit, non fallaces et impostores, ut Socrates apud Platonem, et Stoici fere omnes uoluerunt, sed interpretes ac nuntios rerum optimarum. Quorum maxima fuit necessitas. Quorundam enim auxilio ad tutandam hanc fouendamque uitam maxime indigemus; reliqui uero ad obscurissimarum rerum intelligentiam, et quaedam fundamenta scientiae maxime sunt necessarii.

Atque ut in primis ab his incipiamus, qui locum in capite tanquam in arce occuparunt, uidebimus certe fulgida illa sidera, quae oculos muncupamus; de quorum [11] artificio, dispositione, solertiaque admiranda, ut dicere omittamus, quis non uidet illos tanquam speculatores uigilantissimos altissimum locum obtinere, unde plurima conspicere, et suo munere optime fungi possint? Quorum beneficio Pindarus ait nos ea, quae in se terra occultat et ultra caelum posita sunt, contemplari. Atque adeo ut nihil nisi perfectum et pulchrum uideremus, creauit Deus uniuersam hanc machinam ea specie et pulchritudine, ut propterea mundum appellemus.

Nam et terram ipsam mira uarietate depinxit, quam praeter fluminum leniter labentium suauitatem, fontium amoenitatem, pratis iucundissimis, campisque colorum diuersitate admirandis ornauit.

Caelum uero ipsum non solum forma perfectissima effinxit, sed etiam illis stellatis luminibus uelut quibusdam gemmis distinxit. Ad cuius uelut ad proprii domicilii, cognationisque contemplationem hominis conspectum excitauit.

Nec solum uoluit haec ut uideret, nam et id brutis ipsis animantibus aliquando fortuito potest euenire; sed ut statas illas perpetuasque orbium conuersiones, siderumque cursus et cognosceret et obseruaret.

Quam obseruationem Astrologiam uocamus. Cuius tanta est excellentia, ut eam non ab homine aliquo inuentam, sed ab ipsis Diis antiqui homines ausi sint affirmare. Itaque alii a Mercurio, alii uero ab Vrania una e nouem Musis, quas etiam uideo Platonem illum ualde approbasse, inuentam [12] esse dicebant.

Primi certe omnium Aegyptiorum sacerdotes illam monumentis tradiderunt, de quibus illud potest dici non immerito,

Felices animae, quibus baec cognoscere primum,

Inque domos superum scandere cura fuit.

Credibile est illos pariter uitiisque locisque

Altius bumanis exseruisse caput.

Vnde nostro quodam iure Socraticum illud, quod supra nos nihil ad nos, possumus contemnere. Sic enim nihil ad nos caelum ipsum, nihil denique lux ipsa pertineat.

Quin multo elegantius Anaxagoras ille, qui se caeli solisque uidendi causa natum esse praedicabat; nec certe mirum. Sic enim Paulus ille Aemilius 
Formou, pois, o corpo não de qualquer maneira, mas direito e aprumado, e belo na sua própria forma e elegância; a ele atribuiu os sentidos, como companheiros, não falazes e impostores, como Sócrates, segundo Platão, e quase todos os Estóicos queriam significar, mas sim intérpretes e mensageiros do que é sublime. Foram de extrema necessidade. Com efeito, carecemos enormemente do auxílio de alguns deles para proteger e suavizar esta vida; os restantes são muito necessários para a inteligência dos assuntos mais obscuros e para certas bases do conhecimento. ${ }^{29}$

E, para que comecemos primeiramente por aqueles que, na cabeça, ocuparam um lugar como numa fortaleza, veremos aquelas fúlgidas estrelas a que chamamos olhos. E para já [11] não falarmos do que é de admirar no seu artifício, disposição e destreza, quem os não verá, como uns observadores vigilantíssimos, conseguir um lugar muito alto, donde possam observar o maior número de coisas e cumprir eficazmente a sua missão?30 Píndaro diz que, graças a eles, contemplamos o que a terra em si oculta e o que está disposto para além do céu. E exactamente para que nada víssemos que não fosse perfeito e belo, criou Deus o universo com tal aspecto e beleza que, por isso mesmo, lhe chamamos mundo. ${ }^{31}$

Assim, pintou a própria terra com admirável variedade e, para além da suavidade dos rios que correm ligeiros e da amenidade das fontes, ornou-a de frescos prados e de campos de cores variadas e dignos de admiração.

Quanto ao céu, não só o representou com uma forma perfeitíssima, como ainda o matizou com essas luzes cintilantes que se assemelham a pérolas dispersas. E excitou a vista do homem para a contemplação do mesmo céu - como sua morada própria - e dos laços que o unem a este. ${ }^{32}$

Mas não quis que ele visse apenas estas coisas, pois o mesmo, casualmente, pode acontecer, por vezes, até com os brutos animais; quis também que conhecesse e observasse essas periódicas e perpétuas revoluções dos orbes e os cursos dos astros.

A esta observação chamamos Astronomia. É tal a excelência que possui, que os antigos ousaram afirmar ter sido descoberta não por algum ser humano, mas pelos próprios deuses. E assim, uns diziam que fora Mercúrio quem a descobriu, outros Urânia, uma das nove musas, as quais, aliás, sei que o célebre Platão [12] decididamente aprovou.

Sem dúvida, os primeiros de todos que a transmitiram foram os sacerdotes Egípcios, nos monumentos, a respeito dos quais pode dizer-se, não sem o merecerem:

Felizes aquelas almas a quem coube o cuidado de, primeiramente,

Conhecerem estas coisas e de subirem até às moradas dos deuses. Acreditamos que elas ergueram sua cabeça acima

Tanto dos vícios, como das guaridas dos mortais. 33

Daí, com um certo direito, podermos desprezar aquela sentença socrática que afirma nada existir acima de nós que tenha relação connosco. Assim, de modo algum está ligado a nós o próprio céu, nem, de resto, a própria luz.

Pelo contrário, com muito mais discernimento, o famoso Anaxágoras proclamava ter nascido para ver o céu e o Sol, ${ }^{34}$ o que sem dúvida não é de admirar. Na verdade, 
apud M. Tullium, P. Scipionem Africanum filium alloquitur: "Animus, inquit, nobis ex illis sempiternis ignibus, quae sidera et stellas uocamus, datus est, quae globosae et rotundae diuinis animatae mentibus celeritate mirabili circulos suos, orbesque conficiunt»; quod idem et diuinus ille Plato affirmat: "Cum enim uniuersum, inquit, Deus constituisset, astris parem numerum distribuit animorum, singulos singulis adhibens, eisque tanquam uehiculis impositis, monstrauit uniuersi naturam, legesque fatales edixit".

Vnde idem existimabat, Astrologiae rationes inquirere, non nisi sapientissimi homines esse, naturaeque admirabilis; quem non nisi feliciter uiuere, et beate emori posse dicebat.

Harum rerum inquisitioni non dubitarunt excellenti ingenio [13] uiri diutius inhaerere. E quibus Pythagoram* illum philosophum paene immortalem uideo, quem primum omnium aiunt eundem Hesperum, quem Luciferum, obseruasse.

Extitit et Eudoxus Platonis auditor in Astrologia doctissimorum hominum iudicio facile princeps.

Huic igitur studio incumbere cum propter se sit gloriosum, tum etiam in primis utile.

Atque ut illud omittamus, uictus nostri causam de caelo esse, illud certe non possumus non maxime amplecti, quod hac doctrina instructi, facile illa contemnimus quae homines uulgo pertimescunt.

Huius siquidem ignoratione aiunt Niciam illum Atheniensium imperatorem propter solis defectum, metuentem classem e portu educere, exercitum omnem amisisse, et Rempublicam uniuersam fere ad perniciem induxisse. Quin et Athenienses ipsos solis obscuratione perterritos, unus Pericles metu liberauit.

Quod idem apud Romanos uideo Sulpicium Gallum in exercitu L. Pauli fecisse, ubi multa de lunae defectione disseruit, ne uelut prodigio diuinitus facto militum animi terrerentur.

Solis autem defectum primus Thales ille Milesius praedixit, post quem uelut naturae socius ac particeps, utriusque sideris cursum in annos sexcentos praedixit Hipparchus.

Atque ut alias ex siderum obseruatione commoditates, ut horarum distinctionem, quam ex solis mutatione primum aiunt Hyperiona illum obseruasse praetermittam; illud certe praetermittere [14] non possum, quod et antiqui sapientes existimarunt. E sideribus nempe ipsis quosdam ueluti igniculos nobiscum ad uirtutem nasci, quos nos multoties aut praua consuetudine, aut molli educatione in uitia conuertimus; sicque fieri ut Saturni

* Suidas Parmenidem ait 
segundo Marco Túlio, Paulo Emílio dirige-se assim ao seu filho Cipião Africano: "A alma é-nos dada a partir daqueles fogos eternos a que chamamos constelações e estrelas que, globosas e rotundas, animadas pelas mentes divinas, executam, com admirável celeridade, os seus círculos e órbitas.»35 E o mesmo afirma o sublime e divino Platão, ao dizer: «Deus, ao constituir o universo, distribuiu um número de almas igual aos astros, atribuindo cada alma a cada astro e, colocando-as aí como em carros, deu-lhes a conhecer a natureza do universo e proclamou as leis do destino. ${ }^{36}$ Por este facto, o filósofo considerava que inquirir as razões de ser da Astrologia e da natureza admirável era próprio apenas do homem sapientíssimo, e acrescentava ainda que esse não podia deixar de viver ditoso e morrer feliz.

Homens de excelente engenho não hesitaram em se aplicar por muito tempo [13] à investigação destas matérias. Dentre eles, vejo o célebre Pitágoras*, filósofo quase imortal, que dizem ter sido o primeiro de todos a observar ser Vésper a mesma estrela que Lúcifer. ${ }^{37}$

Salientou-se também Eudoxo, discípulo de Platão, na opinião incontestada dos mais doutos homens, o primeiro na Astrologia. ${ }^{38}$

Concluindo, pois, aplicar-se a este estudo será uma tarefa não só gloriosa com respeito a si próprio, como útil, acima de tudo.

Mas, embora não desenvolvamos a ideia de que a razão do nosso viver vem do céu - não podemos, todavia, deixar de abordar, de modo especial, o seguinte: que, se estamos instruídos por esta ciência, facilmente desprezamos aquelas situações que os homens vulgarmente temem.

Com efeito, a ignorância da Astronomia, segundo dizem, levou Nícias, o famoso general ateniense, devido a um eclipse do Sol, a retirar, receoso, a armada do porto, a licenciar todo o exército, e a conduzir assim a República inteira à beira da ruína. ${ }^{39}$

Pelo contrário, Péricles foi o único que conseguiu libertar do medo os próprios Atenienses, aterrorizados pelo obscurecimento do Sol.

E em Roma vejo que Sulpício Galo fez o mesmo no exército de Lúcio Paulo, quando dissertou acerca de um eclipse total da Lua, não fossem os ânimos dos soldados atemorizarem-se com esse facto, como se ele fosse um prodígio enviado pelos deuses. ${ }^{40}$

Por sua vez, Tales de Mileto foi o primeiro que anunciou um eclipse do Sol. Depois dele, Hiparco, por assim dizer o amigo e companheiro da natureza, predisse para 600 anos a duração do curso de ambos os astros. ${ }^{41}$

Não me referirei às diferentes vantagens da observação dos astros, como a distinção das horas, que dizem ter sido observada pela primeira vez por Hiperíon, a partir da mutação do Sol; contudo, de modo nenhum, [14] posso omitir o que chegaram a pensar os sábios antigos.

Seguramente, dos próprios astros nasceram connosco como que umas centelhas que nos impelem à virtude, as quais, por um mau hábito ou educação mole, convertemos

\footnotetext{
* Suídas diz que foi Parménides.
} 
grauitatem et parsimoniam, in tristitiam et auaritiam; Martis magnanimitatem, in audaciam et temeritatem; Veneris gratiam, uenustatem et in omnibus rebus decorum, in lasciuiam et foedissimam libidinem; Mercurii denique industriam, in fraudem et astutiam conuertamus.

Quod usque adeo illi uerum putabant, ut ex astrorum obseruatione futurorum praedictiones sibi uindicarent. Quas si uellem persequi, multa et admiranda possem adferre. Verum ab eo me non solum Archelaus ille et Cassandrus summi astrologi, qui totam hanc futurorum praedictionem contempserunt, sed etiam Christiana religio reuocauit.

Sed iam ab oculis paululum delapsi, si hominem ipsum inspexerimus, inueniemus aures non solum loco et situ, sed ornatu etiam mirabiles. Quas geminas tantum summus ille rerum omnium parens esse uoluit, tum quia ad speciem et pulchritudinem duorum numerus perfectissimus est, tum quia non plures ad admittendum utrimque aduenientem sonum sunt necessariae. Quarum si quis sinuosos illos flexuososque anfractus consideret, admirabile quoddam opus uidebit. Harum usum cum ad omnes alias scientias perdiscendas necessarium, [15] tum maxime ad Musices harmoniam numerumque percipiendum diuinus ille Plato dicebat.

In Musices autem studio Graeci homines et summam eruditionem ponebant, et ei diuinitatem quandam inesse existimabant, ut manifestum plane sit, illos non hanc, quam ad aurium uoluptatem tantum libidinesque hominum nequitia conuertit, intellexisse; sed illam, sine cuius harmonia mundum ipsum Pythagoras nec compositum nec concinnatum fuisse putat.

Quam P. ille Cornelius Scipio ex orbium conuersione, et siderum cursu percipiens apud M. Tullium sic patrem Paulum interrogat: "Quis est hic, qui complet aures meas tantus et tam dulcis sonus?» Musicem apud Platonem Timaeus a praepotenti Deo hominibus concessam dicit, ut si quid externum eorum animos turbauerit, huius concentu sedari, et in ordinem possint redigi.

Huius suauitate non solum

Siluestres homines sacer interpresque Deorum

Caedibus et uictu foedo deterruit Orpheus;

sed et bruta ipsa animantia feritatem deposuisse, omnes omnium historiae profitentur.

Rationemque dum Platonici conantur afferre, aiunt caelestem animam, qua uniuersitas haec animatur, e Musica originem sumpsisse; nihilque mirum, si

\section{Dictus et Amphion Thebanae conditor arcis}

Saxa mouere sono testudinis.

Hoc uelut maximum Dei munus agnoscens Socrates [16] ille Apollinis oraculo sapientissimus iudicatus etiam senex lyra institui non erubuit. Nec enim erat cur aut maximi Apollinis, aut optimi Mercurii contemneret 
muitas vezes em vícios, ${ }^{42}$ e assim acontece que transformamos a gravidade e parcimónia de Saturno em mau humor e avareza; a magnanimidade de Marte em audácia e temeridade; a graça e a formosura de Vénus e o seu decoro em todas as coisas, em lascívia e sensualidade indigna e, finalmente, a habilidade de Mercúrio em perfídia e manha.

De tal forma os sábios antigos tomaram estas afirmações como verdadeiras, que reivindicavam para si as predições do futuro pela observação dos astros. E, se eu as quisesse expor, poderia contar muitos e admiráveis factos. Mas não só Arquelau e Cassandro, sumos astrólogos que desprezaram toda esta predição do futuro, ${ }^{43}$ como também a religião cristã, de tal me dissuadiram.

Se repararmos no homem em si, deslizando já um pouco a partir dos olhos, encontraremos as orelhas, admiráveis não só pelo seu lugar e disposição, mas também pela sua graça. Quis o Supremo Criador de todas as coisas que as orelhas fossem só duas, já porque o número dois é o mais perfeito para ornamento e beleza, já porque não são necessárias mais para receber o som que vem de ambos os lados. E se alguém reparar nessas sinuosidades recurvadas e tortuosas, ${ }^{44}$ descobrirá uma obra digna de se ver.

O insigne e divino Platão dizia que era necessário o seu uso para a perfeita aprendizagem [15] das diversas ciências, mas sobretudo para a percepção da harmonia e cadência da Música.

Os Gregos colocavam no estudo da Música uma superior erudição e julgavam mesmo existir nela alguma divindade. É bem evidente que eles não reconheciam como música a que a nequícia dos homens converteu somente em prazer e deleite dos ouvidos, mas sim aquela sem cuja harmonia Pitágoras pensa que o próprio mundo não teria sido formado e adornado. ${ }^{45}$

O famoso Públio Cornélio Cipião, ouvindo-a a partir da revolução dos orbes e do curso dos astros, interroga assim seu pai, Paulo, segundo Marco Túlio: "Que som é este, tamanho e tão doce, que me enche os ouvidos?" 46 Timeu, em Platão, diz que a Música foi concedida aos homens por Deus todo-poderoso, para que, se algo exterior lhes perturbar o espírito, possam, com a sua harmonia, acalmar-se e regressar à ordem. ${ }^{47}$

Graças à suavidade da Música, não só

Orfeu, sagrado medianeiro dos deuses, afastou os homens selvagens dos morticínios e do viver indigno;

mas até os brutos animais cessaram com a sua ferocidade, segundo testemunham todas as narrativas. ${ }^{48}$

E os platónicos, ao pretenderem alegar uma explicação, dizem que o sopro divino, que anima este universo, recebeu da Música a sua origem. ${ }^{49}$ Nem é de admirar, porquanto

\section{Se diz que Anfíon, fundador da fortaleza de Tebas,}

removia as pedras ao som da lira. ${ }^{50}$

O grande Sócrates - considerado sapientíssimo pelo oráculo de Apolo reconhecendo [16] esta arte como o maior dom de Deus, ${ }^{51}$ não se envergonhou de aprender a tocar a lira, já quando velho. ${ }^{52}$ Nem havia razões por que desprezasse 
inuentum. Huic etiam studio uideo Aristoxenum summum philosophum se totum addixisse, tresque sonorum species constituisse, Harmonicon, Diatonicon et Chromaticon. At diuinus ille Plato altius rem repetens, Musicem omnem in Mundanam, Humanam et Organicam distribuit.

Haec igitur qui intelligit, nonne uidet Aegyptiorum hominum temeritatem, qui rem sanctissimam uelut ignauam, animorumque effeminatricem et dammabant et fugiebant? An non uidebant homines illi, nihil tam sanctum esse, quo hominum nequitia abuti non possit? De hominibus igitur illi aliquid, de re certe nihil dixerunt. Nec enim si id ita esset, aut Epaminondam illum Graeciae facile principem tantopere Musica commendaret, aut Themistoclem Musices ignarum ut rusticum notatum uideremus.

Vnde et Lacedaemoniorum legislator seuerissimus Lycurgus Musicem, quantum potuit, in suam Rempublicam induxit; nec immerito. Videbat enim huius non solum domi, sed etiam foris maximam uim esse.

Hac enim militum animi ad subeunda quamuis grauissima pericula facile inuitantur, et iam bello fracti consternatique et reficiuntur et excitantur.

Ad hanc unam Arcades austerioris uitae homines, ut duritiem asperitatemque morum temperarent, [17] et assiduos in agris colendis labores subleuarent, confugiebant; apud quos cum ceteras artes ignorasse nulla esset ignominia, Musicem tamen ignorare nemo poterat.

Hac in re, ut alios praetermittam, unus maxime excelluit Timotheus, cui tantum supererat artis, ut quoties libuisset, et uehementi acrimonia hominum animos incenderet, et rursus molli ac placida leniret. Hic cum in Alexandri conuiuio cantum eum, quem Phrygium appellant, modularetur, usque adeo Regem excitauit, ut ad arma capienda prosiliret, eundemque iterum mutata modulatione ad epulas reduxit.

Nec eam uim hominis esse quisquam existimet, sed harmoniae. Nam et Pythagoram illum, cum iuuenes uino saltuque lasciuientes uidisset, iussisse ferunt ei, qui modos faceret, ut mutata harmonia Doricum personaret, quod ubi factum est, bacchantes illos resipuisse ferunt, relictisque omnibus cum pudore domum abiisse.

Verum nec minus circa aures nostras numerus ipse uersatur. Sine cuius ratione, non solum Musica ipsa, sed ne scientia quidem ulla potest consistere.

Hominemque ipsum ideo animal sapientissimum Plato putabat, quod numeros intelligeret, Arithmeticemque ipsam inter omnes artes libero homine dignas praecipuam et maxime diuinam constituebat, numerorumque scientiam singularem philosophis supellectilem existimabat.

Ac tanto magis nunc dolendum est, quanto [18] magis hanc uidemus a philosophorum scholis neglectam, a sordidis hominibus et faeneratoribus abreptam ad pessimos usus esse conuersam. Cuius homines isti ne umbram quidem unquam uiderunt, sed nescio quam quaestuariam rationem, diuino 
o invento do ilustre Apolo ou do excelente Mercúrio. Vejo também que Aristóxeno, grande filósofo, se dedicou inteiramente a este estudo e estabeleceu três espécies de som: Harmónico, Diatónico e Cromático. ${ }^{53}$ E o preclaro e divino Platão, retomando o assunto mais profundamente, dividiu toda a Música em Universal, Humana e Orgânica. ${ }^{54}$

Ora, quem isto conhece não vê, porventura, a temeridade dos Egípcios, que condenavam esta arte sacratíssima, considerando-a ignava e efeminadora dos espíritos e evitando-a por esse motivo? Não viam eles que nada há tão sagrado, de que a nequícia dos homens possa fazer mau uso?55 - Enfim, algo disseram os Egípcios acerca do Homem; nada, sem dúvida, acerca da Música. Se assim não fosse, nem a Música valorizaria tanto o célebre Epaminondas, incontestavelmente o primeiro homem da Grécia, ${ }^{56}$ nem veríamos Temístocles considerado rude pelo facto de a ignorar. ${ }^{57}$

Por isso, Licurgo, o severíssimo legislador da Lacedemónia, introduziu, quanto pôde, a Música na sua República, e com razão, pois via ser ela a força máxima quer do lar, quer fora dele. 58

Por meio dela, os espíritos dos soldados são incitados a vencer sem dificuldade os perigos, por mais graves que sejam e, quando enfraquecidos e atemorizados pela guerra, a Música reanima-os e estimula-os. ${ }^{59}$

Os Árcades, homens de vida um tanto austera, só nela se refugiavam, a fim de moderarem a dureza e severidade dos costumes [17] e suavizarem os constantes labores na cultura dos campos. Entre eles, embora não fosse nenhuma desonra ignorar as restantes artes, ninguém, no entanto, podia ignorar a Música. ${ }^{60}$

Nesta matéria, sem referir outros, um mormente se salientou - Timóteo - que possuía tanta arte, que, sempre que lhe aprazia, não só incendiava os espíritos dos homens com uma veemente energia, como, em seguida, os acalmava com uma energia branda e plácida. Este músico, ao entoar, num banquete de Alexandre, aquele canto a que chamam frígio, de tal forma animou o Rei, que o impeliu a tomar as armas e, mudando de novo a melodia, o reconduziu ao festim. ${ }^{61}$

Mas ninguém julgue ser essa força própria do homem; é-o, sim, da harmonia. Com efeito, o insigne Pitágoras, como visse uns jovens folgando com o vinho e a dança, segundo dizem, ordenou ao que marcava o ritmo, fizesse entoar o canto Dórico, mudando a harmonia; e, quando isto se efectuou, aqueles mancebos delirantes retomaram os seus sentidos e, deixando tudo, retiraram-se para casa, envergonhados. ${ }^{62}$

Não menos o próprio número perpassa em redor dos nossos ouvidos. Sem a compreensão dele, não só a própria Música, como nenhuma ciência, pode subsistir. Platão julgava o homem um ser sapientíssimo, porque entendia os números ${ }^{63}$ e colocava a Aritmética como a primeira e a mais divina de todas as artes dignas de um homem livre. ${ }^{64}$ Considerava a ciência dos números como uma ferramenta singular para os filósofos.

Nos dias de hoje, vemos que tanto mais é de lamentar, quanto [18] mais ela é desprezada pelas escolas dos filósofos e, arrastada por homens ignóbeis e usurários, é alterada para os piores usos. Dela esses homens nunca viram sequer a sombra, mas, profanando o nome divino da Aritmética, correram atrás não sei de que espécie 
Arithmetices nomine ementito, sunt consectati. Quam Lycurgus ille uelut popularem ac turbulentam minimeque homine dignam e Republica eiecit.

Ingenio ac mente diuiniore opus est ei qui Arithmeticam illam simplicem ac puram uoluerit contemplari.

Quam cum Pythagoras ille admiraretur, nescio quid diuinius inueniebat quod nec oculis uideri nec sensibus percipi poterat, existimabatque aut animum ipsum numerum esse, aut saltem certa quadam numerorum constitutione animos corporibus associari.

Sed quid? An non et sacrae ipsae litterae nos docent Deum Optimum Maximum omnia numero, pondere mensuraque perfecisse? Quid? An non Socrates ille apud Platonem mundi compositionem probaturus, a numeris ipsis incipiendum putauit? quos ad eam rem nec plures tribus, nec pauciores esse uoluit. Non igitur mirum si et Pythagoras in numeris et siderum ambitus et animalium productiones constituebat, tantamque diuinitatem in unitate reponebat, ut eam solam diceret caeli temperiem, animis uirtutem, sanitatem corporibus, domibus ac ciuitatibus pacem immittere, nosque ex ea [19] uirtutum omnium initium finemque accipere. Sed dies me deficeret, si monados triadosque diuinitatem, si quaternarii, quinariiue stabilitatem et potestatem, si denique nouenarii perfectionem uellem persequi.

Hoc unum dicere satis sit, tantam esse Arithmetices excellentiam, ut eam non modo philosophi, sed ne imperatores quidem ipsi sine ignominia possint ignorare. Siquidem et apud Homerum Agamemnonem illum uidemus ut stolidum notatum, quod numeros ignorauerit; nec certe aliter fieri potuit. Siquidem et diuinus ille Plato Arithmeticen omnium maxime et ingenium acuere, et memoriam confirmare, et animum ad omnem contemplationem efficere multo promptiorem existimauit.

De qua plura dicerem, nisi et Geometriam uiderem non minus circa numeros, quam circa formas, magnitudines, lineamenta et interualla occupatam; quam nullo modo possum tacitam praetermittere. Hanc siquidem uideo et apud Graecos in summo honore habitam fuisse, et a sapiente illo Pythagora inter primas mathematicarum artium annumerari.

Cuius scientiae tanta est certitudo, ut hi cogere, non persuadere dicantur; apud quos uidemus extrema primis, media utrisque, omnia omnibus respondere. Huius expertem discipulum diuinus ille Plato non admittebat,

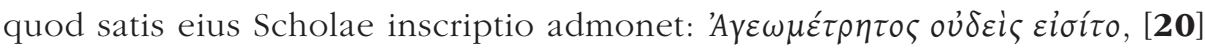
quoniam, ut ille inquit, haec hominum animos terrenis his inhaerentes, ad aeternam illam naturam, quae intellectu tantum concipitur, diuinarumque rerum contemplationem erigit atque excitat; haec in eius quod semper est cognitione uersatur, haec essentiam ipsam per se ac puram contemplatur; quod certe totius philosophiae finis est. Atque ideo non immerito Alcinous 
de desonestos cálculos lucrativos. ${ }^{65} \mathrm{E}$ até o notável Licurgo, acusando-a de populista e turbulenta e nada digna do homem, eliminou-a da República. ${ }^{66}$

Engenho e mente um tanto divina são necessários àquele que quiser considerar a Aritmética simples e pura.

Pitágoras admirava-a e não sei que lhe encontrava de divino que não podia ver-se com os olhos nem apreender-se com os sentidos. Julgava que a própria alma era um número, ${ }^{67}$ ou que, pelo menos, as almas se associavam aos corpos por uma certa disposição de números. ${ }^{68}$

Mas porque não? Porventura as Letras Sagradas não nos ensinam que Deus Óptimo Máximo tudo executou com número, peso e medida? ${ }^{69}$ Pois quê? Acaso o grande Sócrates, segundo Platão, não julgou dever começar pelos próprios números, para provar a composição do mundo? Para esse efeito, não quis mais nem menos que três.

Não nos admiremos, pois, se Pitágoras fixava em números as órbitas dos astros e as reproduções dos animais. ${ }^{70} \mathrm{E}$ tanta divindade atribuía à unidade, que dizia só ela favorecer a amenidade do clima, a virtude nas almas, a saúde nos corpos, a paz nos lares e nas cidades $;{ }^{71}$ dizia ainda que dela [19] recebemos o princípio e o fim de todas as virtudes.

Mas um dia não me bastaria, ${ }^{72}$ se eu quisera expor a divindade da mónade e da tríade, a estabilidade e o poder do quaternário e quinário e, finalmente, a perfeição do novenário. ${ }^{73}$

Basta dizer só isto: tão grande é a excelência da Aritmética, que nem só os filósofos, como nem mesmo os próprios generais podiam ignorá-la sem desonra. Vemos, com efeito, que, em Homero, o famoso Agamémnon é considerado estulto por ignorar os números. Nem podia ser de outro modo, já que o divino Platão tinha como certo que a Aritmética aguçava maximamente o engenho de todos, consolidava a memória e tornava o espírito muito mais apto a todo o tipo de especulação. ${ }^{74}$

Acerca da Aritmética muito mais diria, se eu não visse a Geometria não menos ocupada dos números, do que das formas, grandezas, linhas e espaços. ${ }^{75}$ Daí que não posso de modo algum deixá-la passar em silêncio. Aliás, vejo que também na Grécia ela foi tida na máxima consideração, ${ }^{76}$ sendo mesmo incluída pelo famoso e sábio Pitágoras entre as primeiras das artes Matemáticas.

Tamanho é o rigor desta ciência, que se diz que os geómetras obrigam, não persuadem: ${ }^{77}$ com eles aprendemos que os termos finais correspondem aos primeiros, os médios a uns e outros, e tudo a todos. ${ }^{78} \mathrm{O}$ preclaro e divino Platão não admitia, como seu discípulo, quem ignorasse a Geometria; e a inscrição da sua escola bem

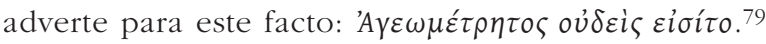

[20] Na verdade, como ele diz, a Geometria estimula os espíritos dos homens, apegados às coisas terrenas, para que se voltem para aquela natureza eterna que só pelo intelecto é apreendida, e eleva-os até à contemplação das coisas divinas; ${ }^{80}$ ocupa-se do conhecimento daquilo que sempre é, considera a própria e pura essência 
ille eorum operam et cogitationem irridere solebat, qui se ad Geometriam alterius alicuius finis gratia conferebant. Est enim, ut ille inquit, cinclo pauperior, et nudior leberide.

Geometriae tamen tanta est excellentia, ac paene diuinitas, ut summus uir Flauius Iosephus dicere non dubitauerit primis illis Aegyptiis Deum Optimum Maximum longiorem uitam concessisse, quod uirtutes ipsas, hoc est, Geometriam et Astrologiam perscrutarentur. Deumque praepotentem diuinus ille Plato omnia geometrica quadam ratione dicit constituisse; nec mirum. Hac enim una ius aequitasque ipsa continetur, haec omnia pro ratione ac dignitate disponit, nil permiscet, bonorum ac malorum insigniter discernit inaequalitatem. Quod cum satis intelligeret Lacedaemonius ille Lycurgus Geometriam in Rempublicam admisit.

Huius figuram cum Socraticus ille Aristippus naufragus et nudus in Rhodiorum** litore descriptam uideret, coepit exultare, sociosque bono animo esse iussit; quod ibi hominum uestigia conspiceret.

[21] At uero si utilitatem spectamus, eam maximam cum Geometria coniunctam inueniemus.

Atque ut omittam Deorum immortalium templa augustissima, domos magnificas, urbes atque arces munitissimas, singularem columnarum elegantiam, Corinthia illa, Dorica, Ionica et Toscana opera, agrorum limites, agricolarum rusticorumque hominum industriam, nihil terrae sine geometrica quadam mensura commitentem, nonne Socrates ille hanc et ad rem bellicam maxime necessariam existimabat? Siquidem hac ac castra ponenda, ad regionem occupandam, ad turmas dilatandas rursusque colligendas, ad machinas denique construendas uti solemus.

Denique id unum dicam, sine Geometria non modo haec, sed nec rerum omnium speciem et pulchritudinem, quae in partium omnium proportione, uenustaque symmetria posita est, posse consistere.

Sed iam ad hominem ipsum iterum redeamus, cuius uultum si adhuc contemplemur, uidebimus oris effigiem et speciem, Deus bone, quam elegantem, quam utilem, quam necessariam cum alia multa, tum maxime ad id quod animo conceperis explicandum.

Cuius primam considerationem Grammatica sibi suo iure uendicat. Quae nominum rationem, elementorumque cognitionem considerat, res quidem, ut maxime necessaria, ita certe et natura prior.

Nec tam exigua, quin Socrates [22] apud Platonem dicat nominum rationem inquirere maximi momenti esse, sine qua, inquit, nec rerum

** Alli Syracusarum. 
por si mesma - o que, seguramente, é o fim de toda a filosofia. Por isso, não sem razão, Alcínoo costumava zombar da obra e cogitação daqueles que se aplicavam à Geometria para um fim de qualquer outra ordem. Com efeito, como ele diz, esse é mais pobre do que o melro de água e mais desnudo que a serpente. ${ }^{81}$

É tão grande a excelência da Geometria e a sua quase divindade, que o ilustre varão Flávio Josefo não hesitou em dizer que Deus Óptimo Máximo concedeu uma vida mais longa aos primeiros e ilustres Egípcios, porque perscrutavam as próprias virtudes, isto é, a Geometria e a Astrologia. ${ }^{82} \mathrm{E}$ o divino Platão afirma que Deus omnipotente criou todas as coisas segundo um determinado cálculo geométrico. ${ }^{83}$ Nem admira, pois só na Geometria se contém o direito e a própria equidade; ela tudo dispõe segundo a razão e a dignidade; nada mistura e, de uma maneira singular, distingue a dissemelhança entre o bom e o mau. Por ter compreendido bem o papel desta ciência, Licurgo, o famoso lacedemónio, introduziu o estudo da Geometria na República. ${ }^{84}$

Como o socrático Aristipo, náufrago e nu, visse desenhada uma figura geométrica na praia de Rodes**, começou de exultar e recomendou a seus companheiros que tivessem coragem, pois aí distinguia vestígios humanos. ${ }^{85}$

[21] Se repararmos na utilidade em si mesma, descobriremos ser muito grande a que acompanha a Geometria.

E, para já não me referir aos templos augustíssimos dos deuses imortais, aos edifícios sumptuosos, cidades e fortalezas bem protegidas, à singular elegância das colunas - aquelas célebres obras coríntias, dóricas, iónicas e toscanas -, aos limites dos campos, à actividade dos agricultores e camponeses, para já não referir quem afirma confiante que nada na terra existe sem uma certa medida geométrica, porventura o grande Sócrates não a julgava extremamente necessária para a estratégia militar? Com efeito, costumamos fazer uso dela para a colocação de acampamentos, ocupação de territórios, aumento e retirada dos batalhões e, finalmente, para a construção das máquinas de guerra.

Numa palavra, sem a Geometria não podem subsistir nem estas vantagens, nem mesmo a forma e a beleza de todas as coisas, a qual reside na proporção, graça e simetria de todas as partes.

Mas voltemos de novo ao Homem.

Se contemplarmos ainda o seu rosto, veremos a forma e o aspecto da sua boca. Santo Deus, quão graciosa ela é e quão útil e necessária para explicar muitas e diversas coisas, mas, acima de tudo, para explicar aquilo que se apreende pelo espírito!

E a primeira reflexão sobre isso é reivindicada, por direito próprio, pela Gramática. Ela considera a natureza dos nomes e o reconhecimento dos elementos, coisa tão prioritária na ordem natural, como extremamente necessária.

Nem a Gramática é de tão pouco valor que Sócrates, [22] segundo Platão, não diga ser da máxima importância inquirir a natureza dos nomes, sem a qual, diz

\footnotetext{
** Ou de Siracusa, segundo outros.
} 
essentiae doceri, nec discerni possent. Cumque ingenue fateatur se in his nescire quid uerum sit, rem tamen diligenti inuestigatione dignam existimat. Quae si quis diligentius contempletur, non solum cognitionem summam, sed et latentem quandam diuinitatem inueniet.

Quod intelligens, M. Fabius ait latere in his multarum rerum subtilitatem, quae non modo puerilia ingenia, sed altissimam eruditionem ac scientiam possit exercere.

Hisque uelut fundamentis iactis iam sese Grammatica ipsa ad Poëtarum tractationem historiarumque cognitionem erigit atque extollit. Grammaticosque ipsos M. Tullius ad poëtarum diuinitatem, quos interpretantur, maxime dicit accedere.

Poesis Poëtas cum dico, absit omnis uerbo inuidia, hominum genus maxime diuinum dico. Quos et sapientes et uates antiquitas appellabat, ac uelut sanctos, hoc est, deorum aliquo dono et munere commendatos uenerabatur. Quin et Socrates cum apud Platonem poëtas deorum interpretes uocaret, poemata ipsa diuina potius, quam humana opera esse existimat.

Quod intelligens ille ait:

Est Deus in nobis, sunt et commercia caeli.

Quare eum qui Archilochum poëtam occiderat sic a templo deus Apollo deterret:

Vatem occidisti, a templo procul ito, profane.

[23] Poëtarum fictiones uideo Chrisippum illum ad Philosophiam traduxisse, quos et Pythagoras et Aristoxenus optimos morum magistros appellabat.

Vnde et ille ait:

Os tenerum pueri balbumque poëta figurat,

Torquet ab obscenis iam nunc sermonibus aurem.

Mox etiam pectus praeceptis format amicis,

Asperitatis et inuidiae corrector et irae.

Poëtas, igitur, qui condemnat, nescio quomodo Mosem illum defendet quem primum omnium tradunt post maris Rubri transgressum carmine hexametro Deo gratias egisse. Quem imitatus Dauid a proeliis expeditus, cantica in Dei honorem componebat. Vnde et Hieronymum interrogantem uidemus: Quid Isaiae Cantico pulchrius? Quid Iob perfectius, quid Salomone grauius?

Sed iam nec his Grammatica contenta Historiam omnem perquirit, quam M. Tullius temporum testem, ueritatis lucem, uitam memoriae, magistram uitae et nuntiam uetustatis appellauit. Sine qua pueri semper sumus. Siquidem quid aliud est, puerum semper esse, quam nescire quid ante nos actum sit? 
ele, não podem ser ensinadas ou discernidas as essências das coisas. Conquanto confesse lealmente não saber o que haja de verdadeiro nestas matérias, julga todavia este assunto digno de uma investigação diligente. E se alguém reflectir mais cuidadosamente nestes pontos, não só descobrirá um superior conhecimento, mas também como que uma divindade escondida.

Compreendendo esta afirmação, Marco Fábio diz que na Gramática se esconde a subtileza de muitas coisas, subtileza essa que não só possibilita o exercício da inteligência das crianças, mas ainda proporciona uma profunda erudição e saber. ${ }^{86}$ Lançados como que estes alicerces, a Gramática já por si se ergue e eleva até ao estudo dos poetas e ao conhecimento da História. ${ }^{87}$

Marco Túlio afirma que os próprios gramáticos se aproximam muito da sublimidade dos poetas, porque os interpretam. ${ }^{88}$

Quando falo em poetas, seja-me permitido dizê-lo, ${ }^{89}$ refiro-me a uma espécie de homens particularmente divina. ${ }^{90}$ A Antiguidade proclamava-os sábios e vates e venerava-os como sagrados, isto é, confiados por algum dom e graça dos deuses. ${ }^{91}$ Mais ainda: Sócrates, segundo Platão, ao chamar aos poetas intérpretes dos deuses, considera os próprios poemas obras antes divinas que humanas.

Porque isto compreendeu, diz o poeta:

Um deus está em nós, estamos também em relação com o céu. ${ }^{92}$

Por isso, o deus Apolo afasta assim, do seu templo, aquele que matara o poeta Arquíloco:

Mataste o vate! Vai-te, impio, para longe do templo! 93

[23] Vejo que o notável Crisipo transferiu para a Filosofia as criações dos poetas, a quem não só Pitágoras, mas também Aristóxeno designavam como os melhores censores dos costumes.

Daí que aquele famoso poeta diga também:

O poeta forma a linguagem terna e balbuciante da criança;

Afasta, desde então, o ouvido, das palavras obscenas;

Forma também, depois, o coração com conselhos amigos.

É o censor da violência, da inveja e da ira..$^{94}$

Portanto, quem condena os poetas não sei como defenderá Moisés, que, segundo dizem, foi o primeiro de todos a render graças a Deus em verso hexâmetro, após a travessia do mar Vermelho. ${ }^{95}$ Imitando-o, David, liberto dos combates, compunha cânticos em honra de Deus. ${ }^{96}$ E vemos Jerónimo que interroga: Que há de mais belo que o cântico de Isaías, mais perfeito que Job, mais grave que Salomão?

Mas a Gramática, não confinada só a estes pontos, inquire toda a História, a que Marco Túlio chamou testemunha dos tempos, luz da verdade, vida da memória, mestra da vida e mensageira do passado. ${ }^{97}$ Sem ela somos sempre crianças. Pois que outra coisa é ser-se sempre menino, senão desconhecer o que antes de nós se realizou? 
Quod cum uideret Aegyptiorum sacerdos antiquissimus, Atheniensem illum Solonem, quamuis sapientum sapientissimum, sic alloquitur: O Solon, Solon, Graeci pueri semper estis, nec quisquam in Graecia senex est. Semper enim uobis iuuenis est animus, in quo nulla ex uetustatis commemoratione prisca opinio, nulla cana scientia est.

Eloquentia At uero quoniam Grammatica ipsa [24] suis limitibus contenta ulterius non progreditur, uerbisque tantum simplicissimis mentis cogitata explicat, Deorum munere facultas multo uberior est hominibus concessa, qua animi consilia copiosius et elegantius explicare et eloqui possent. Hanc Graeci Rhetoricem, Romani Eloquentiam uocarunt; quasi quandam copiose loquentem sapientiam.

Cuius tanta est excellentia ut eam Sophocles rerum omnium dominam ac reginam appellet. Nec certe immerito, si quidem hanc et pacis comitem, et otii sociam, et bene constitutae ciuitatis uelut quandam alumnam esse uidemus. Vnde summo ingenio uir Aristoteles ait, non nisi tyrannis e Sicilia eiectis, Siculos homines ad eloquentiae studium animum adiecisse.

Tyrannide enim, ut ceterae omnes uirtutes, ita etiam maxime eloquentia euanescit.

Haec siquidem una et ad uirtutem ardentius cohortari, a uitiis acrius reuocare, improbos uituperare asperius, bonos laudare ornatius cupiditatemque uehementius frangere solet accusando. Quae cum sublata sunt, non modo praeclara aliqua Respublica, sed ne uel minima quidem hominum societas potest consistere.

Siquidem hac, ut M. Tullius inquit, cohortamur, hac persuademus, hac consolamur afflictos, hac perterritos a timore deducimus, hac gestientes comprimimus, hac cupiditates iracundiasque restinguimus, haec nos iuris, legum, urbium societate deuinxit, [25] haec a uita immani et fera segregauit.

Nec certe alios aut philosophos, aut iureconsultos, aut imperatores denique excellentes fuisse uidebimus, nisi eos qui sese maxime eloquentiae tradiderunt. Atque ut alios omittamus, Themistocles certe ille, Pericles et Theramenes, non solum rerum gestarum gloria conspiciendi, sed et incredibili eloquentia in Republica admirandi uersabantur. Eamque summi illi imperatores non solum sibi ornamento, sed et maxime necessariam existimabant.

Nam quomodo sine hac aut fractos iacentesque militum animos excitare, aut ferociores refrenare, aut denique dubius poterit confirmare? Quomodo sine eloquentia aut homines mortem optare incipient, aut saltem timere desistent? Quomodo denique sine hac quisquam aut grauissimos labores contemnet, aut dolores mortisque metus ex animo deponet?

Hanc igitur cum diuinus ille Homerus imperatori maxime necessariam uideret, in Achillis clypeo causas et oratores depictos fuisse dicit; eloquentemque ipsum non hominem, sed deum quendam appellat. 
Como compreendia bem esta questão, um sacerdote egípcio muito notável falou assim ao ateniense Sólon, apesar de ser o mais sábio dos sábios: "Ó Sólon, Sólon, vós, os Gregos, sois sempre crianças, e na Grécia ninguém há que seja velho. É sempre jovem a vossa alma; nela não há nenhuma crença antiga proveniente da lembrança da velhice, nenhuma ciência encanecida". ${ }^{98}$

Ora, porque a Gramática, [24] contida nos seus próprios limites, não vai mais longe, e explica os conceitos apenas por palavras muito simples, uma faculdade muito mais fecunda foi concedida aos homens, como um dom dos deuses, pela qual possam expor e desenvolver com mais eloquência e elegância as deliberações do espírito. Os Gregos chamaram "Retórica" a esta faculdade e os Romanos "Eloquência" - uma espécie de sabedoria que se exprime copiosamente.

Tão grande é a excelência que ela possui, que Sófocles a chama senhora e rainha de todas as coisas. ${ }^{99}$ E não sem que ela o mereça, se virmos que é a companheira da paz e a amiga das horas de lazer e como que filha de uma sociedade bem constituída. Assim, Aristóteles, homem do maior talento, diz que, não tendo sido expulsos da Sicília senão os tiranos, os Sículos entregaram o seu espírito ao estudo da Eloquência. ${ }^{100}$ Com efeito, durante a Tirania, tal como todos os outros valores do espírito, também a eloquência se dissipou profundamente.

Só ela, de facto, costuma, ao mesmo tempo que censura, exortar mais calorosamente à virtude; afastar mais energicamente dos vícios; repreender, com mais aspereza, os maus; louvar, com mais elegância, os bons e, com mais veemência, refrear a cobiça. ${ }^{101}$ Quando estas vantagens são suprimidas, não só nenhum preclaro governo pode subsistir, como nem sequer nenhuma sociedade humana, por mais pequena que seja.

Como afirma Marco Túlio, com a Eloquência exortamos, persuadimos, consolamos os aflitos, afastamos do medo os aterrorizados, reprimimos os demasiado expansivos, extinguimos as cobiças e as iras; ela nos vinculou à comunidade do direito, das leis, das cidades [25] e nos afastou de uma vida desumana e selvagem. ${ }^{102}$

E veremos que, entre filósofos, jurisconsultos ou, enfim, generais, não foram excelentes senão aqueles que se dedicaram, em elevado grau, à eloquência. E, para não nos referirmos a outros, tomaram parte na vida política, sem dúvida o famoso Temístocles, Péricles e Terâmenes, sendo não só notáveis pela glória dos seus feitos, mas ainda dignos de admiração pela sua eloquência inacreditável. Os generais mais eminentes, além de a considerarem como uma honra para si próprios, julgavam-na extremamente necessária.

$\mathrm{Na}$ verdade, sem ela, como se poderão fazer ressurgir os ânimos enfraquecidos e abatidos dos soldados, refrear os mais ferozes, ou encorajar os indecisos? Sem ela, como começarão os homens a desejar a morte ${ }^{103} \mathrm{ou}$, pelo menos, como deixarão de a temer? Finalmente, sem ela, como deixará alguém de recear os árduos trabalhos ou as dores, e afastará do seu espírito o medo da morte?

Como o sublime e divino Homero visse que a Eloquência era extremamente necessária a um general, conta que foram pintadas, no escudo de Aquiles, situações e oradores $^{104}$ e chama ao próprio orador não um homem, mas verdadeiramente um deus. 
Verum eloquens ipse quamuis per se satis excellens sit, tamen, Deus bone, quanto erit excellentior ac diuinior, si incredibili dicendi facultati uicinam illam ac finitimam dialecticorum scientiam adiungat! Sine qua, qui in reliquarum doctrinarum inquisitione et studio uersantur, non minus mihi temerarie [26] facere uidentur, quam qui in Cretensium labyrintho errantes, sese inde sine aliquo Daedalo putant euasuros.

Nam quod magis praeposterum studium esse potest, quam sic uelle in scientiarum cognitione uersari, ut non intelligas quae uera, quae falsa sint, quorum tractationem uniuersam sibi una Dialectica uindicauit?

Sine hac existimabat M. Brutus sicut nec eloquentiam, ita etiam nec reliquas scientias nos posse consequi.

Atque, ut alios omittam, nunquam certe Seruius ille Sulpicius in Iuris prudentiae studio tam excellens extitisset, nisi (ut cum M. Tullio loquar) artem hanc omnium artium maximam, et quasi lucem, ad ea quae ab aliis tractabantur et respondebantur, adiunxisset.

Haec certe una rem uniuersam docet in partes distribuere, latentem definiendo explicare, obscuram explanare interpretando, ambigua primum uidere, deinde distinguere, postremo habere regulam qua uera et falsa iudicentur; et quae quibus propositis sint quaeque non sint consequentia.

In hac uideo summos omnes philosophos diligentissime elaborasse, in qua Antipater et Archidemus principes extiterunt.

Dialectices uim cum stoici perfectius intelligerent, Dialecticam ipsam, ad eas uirtutes de quibus ipsi disputabant, uirtutis nomine adiungebant. Quin et Socrates ipse apud Platonem cum reliquias scientias pertractasset, inquit: Sed quominus eas scientias supremas [27] appellemus, una nos disserendi prohibet facultas quae cum omnem adiunctam peritiam habeat, et circa id, quod est, ut uere est, penitus uersetur, arbitror omnes, quibus aliquid sanae mentis adsit, hanc omnium et dignissimam et uerissimam esse concessuros.

Diximus, auditores optimi, ut potuimus breuissime de omnibus his artibus, quae quia homine libero maxime sunt dignae liberales uocantur, quas ut ignorare turpe est, ita etiam in his consenescere est parum gloriosum.

Superest iam ut ad eas ueniamus quae uelut ceterarum omnium principes altiorem ac profundiorem cognitionem desiderant. Quas cum non secus quam aduersum solem caligantibus oculis intueor, Deus bone, quanta maiestas, quanta amplitudo, quanta denique diuinitas sese mihi offert!

De quibus certe tunc existimo satis dici, cum nil dicitur, et tacite praetermissae uniuscuiusque animo relinquuntur aestimandae. Nec unquam alia in re magis, quam in hac Timanthis illius Cythnii tabellam, qua Colotem Teium superauit, imitandam esse existimarem. Verum quoniam uos aliud uelle sentio, rem quamuis omnium grauissimam aggrediar, feramque multo 
Se bem que o orador seja, já por si, assaz excelente, quanto mais excelente e sublime não será, Santo Deus, se à incrível faculdade oratória juntar aquela ciência dos dialécticos que lhe é tão próxima e afim! ${ }^{105}$

Sem esta, os que se entregam à investigação e estudo das restantes artes parecem-me agir [26] não menos temerariamente do que aqueles que, errantes no labirinto de Creta, julgam se hão-de evadir daí sem a ajuda de um Dédalo.

Com efeito, que trabalho pode ser mais fora de propósito do que querer debruçar-se sobre o estudo das ciências sem que se distinga o que é verdadeiro e o que é falso? ${ }^{106}$ Só a Dialéctica reivindicou para si todo o exercício destes conceitos.

Marco Bruto entendia que, sem ela, não é possível compreender nem a eloquência nem, do mesmo modo, as restantes ciências.

E para já não falarmos de outros, nunca o famoso Sérvio Sulpício teria sido tão excelente no estudo da Jurisprudência, se (conforme as palavras de Marco Túlio) não tivesse acrescentado esta arte - a maior de todas e como que uma luz para elas - àquilo que era tratado e refutado pelas outras. Sem dúvida, só a Dialéctica ensina a dividir o todo em partes; a explicar o oculto, definindo; a esclarecer o obscuro, interpretando; a considerar, primeiro, o que é ambíguo; depois, a distinguir e, por fim, a aplicar a regra pela qual se julgue o que é verdadeiro e o que é falso e aquilo que, perante premissas apresentadas, é ou não a sua consequência. ${ }^{107}$

Verifico que todos os grandes filósofos se aplicaram muito diligentemente à Dialéctica, na qual se salientaram em primeiro plano Antípatro e Arquidemo. ${ }^{108}$

Como os Estóicos compreendessem assaz perfeitamente a força da Dialéctica, juntavam esta arte, com o nome de virtude, àquelas mesmas sobre as quais eles próprios discorriam. ${ }^{109}$ Mais ainda: o próprio Sócrates, segundo Platão, tendo estudado profundamente as restantes ciências, afirma: Mas só a dialéctica nos impede de que chamemos [27] supremas àquelas ciências, e, porque ela tem unida a si toda a perícia e se ocupa com profundidade daquilo que é, quando é de facto, julgo que todos aqueles que possuam alguma sensatez hão-de acabar por considerá-la como a mais digna e verdadeira de todas.

Havemos falado, mui benévolos ouvintes, o mais brevemente que pudemos, acerca de todas aquelas artes que, porque são altamente dignas de um homem livre, se chamam liberais. ${ }^{110}$ Ignorá-las é tão degradante, quanto é pouco glorioso envelhecer nessas circunstâncias.

É já tempo de nos voltarmos para aquelas que, como as primeiras de todas as restantes, exigem um estudo mais alto e mais profundo. Quando as observo, obscurecido o olhar, como se contemplara o Sol, Santo Deus, quanta majestade, quanta grandeza, quanta divindade, enfim, se me oferecem!

Julgo dizer-se o suficiente acerca destas artes, quando nada se diz e, tacitamente omitidas, são deixadas no espírito de cada um, para que sejam apreciadas. Nunca noutra matéria, mais do que nesta, eu pensei que devia ser imitada a pintura de Timantes de Cítnio com a qual superou Colotes de Teos. ${ }^{111}$ Todavia, porque sei que sois de outra opinião, passarei a outro assunto, não obstante ser o mais importante de todos, e 
aequiori animo facundiam desiderari, quam a uobis in me officium requiri; uestraeque humanitatis erit me et sudantem et anhelantem qua coepistis attentione beneuolentiaque audire.

[28] Et quoniam, ut initio dicebamus, excellens hoc animal corpore infirmo et caduco constabat, diuino munere est hominibus Medicina concessa, quae circa corpus ipsam uersaretur, illudque non solum ab aduersa ualetudine conseruaret, sed iam lapsum in pristinam sanitatem reduceret. Atque ideo non immerito ab Herophilo Medicina scientia salubrium et insalubrium et neutrorum dicta est. Quod etiam uideo Hippocratem illum Coum ualde approbasse.

Huius scientiae tanta est excellentia, ut eam antiqui non ab alio, quam ab Apolline, inuentam fuisse dicant; Aesculapiumque eam hominibus tradidisse, eiusque liberos Podalyrium et Machaona in ea excellentes extitisse. Machaona certe, ut singularem imperatorem et excellentem medicum uideo ab Homero commendari. Qui cum in bello Troiano grauiter esset uulneratus, seruari cupiens, ait:

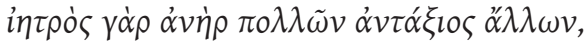

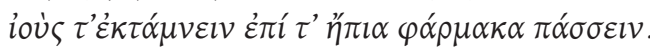

Medicamentorum certe uim cum ueteres homines admirarentur, non iam

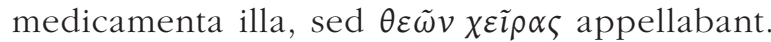

Harumque rerum professores etiam delubris excitatis tanquam deos uenerabantur. Vnde et pro diis cultos Aesculapium, Podalyrium, Machaona, Chironem et Hippocratem Coum accepimus. Cuius etiam natalis dies apud Coos festus habebatur. Quin et apud Aegyptios primus anni mensis a Thoone [29] primo apud illos Medicinae inuentore est cognominatus; quod praesentiens Hebraeorum doctrina iubet medicum honorari, quia eum propter necessitatem creauit Altissimus. Nam cum sanitatis Deus Optimus Maximus auctor sit, eiusque instrumentum natura, utrisque certe medicus minister est.

Quare cum Socrates de Medicina loquitur, hanc unam ait esse earum quae ad bonum tendunt; ad quam non solum uidemus summos philosophos, sed maximos etiam reges se contulisse.

Siquidem Hermes ille Aegyptiorum rex non solum his uirtutibus, quae regem decent, uoluit excellens esse, sed etiam Medicinae cognitione admirandus. Quod idem Mithridatem illum Persarum regem fecisse uideo.

Medicum, igitur, qui contemnit, secundum post Deum uitae auctorem contemnit; et sese hostem lucis ac uitae profiteatur est necesse.

Medicinam, quae solum corpus contemplatur, si tantopere antiqui homines commendarunt, quanto nos magis et admirari et uenerari ea par est quae non corpus, sed animum ipsum tractant, ac perficiunt!

Tanto certe haec sunt excellentiora, quanto corpore animus est diuinior, quem et sempiternum et immortalem esse, non solum Christiani homines credimus, sed et Pherecidem illum Cyrum primum uideo dixisse, eius 
suportarei com muito mais resignação que lamenteis em mim falta de facúndia do que falta do cumprimento do dever. E será próprio da vossa bondade ouvir-me - a mim que já estou suado e ofegante - com a atenção e benevolência com que começastes.

[28] Visto que, como dizíamos no início, este animal excelente constava de um corpo enfermo e caduco, foi concedida aos homens, como dom divino, a Medicina, para que se ocupasse do próprio corpo e não só o defendesse da doença adversa, mas também, uma vez desfalecido, o restituísse à primitiva saúde. Por tal, e não sem que ela o mereça, a Medicina foi chamada por Herófilo a ciência dos sãos, dos doentes e dos neutros. ${ }^{112}$ Hipócrates de Cós aprovou inteiramente esta definição.

É tal a superioridade desta ciência, que os antigos dizem ter sido descoberta não por qualquer humano, mas por Apolo, ${ }^{113}$ tendo sido confiada aos homens por Esculápio, e que nela foram excelentes os filhos deste - Podalírio e Macáon. De facto, vejo que Macáon é elogiado por Homero como singular general e médico excelente, o qual, tendo sido ferido gravemente na guerra de Tróia, desejoso de se curar, murmura:

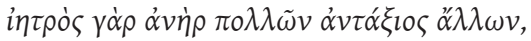

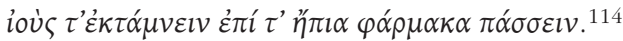

$\mathrm{Na}$ verdade, os antigos admiravam a força dos remédios, chamando-lhes por

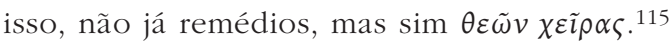

Os mestres desta ciência eram também venerados como deuses, em templos edificados para esse fim. Donde o terem chegado até nós, honrados como deuses, Esculápio, ${ }^{116}$ Podalírio, Macáon, Quíron e Hipócrates de Cós. O dia do aniversário deste era tido em Cós como dia festivo. Mais ainda: no Egipto, o primeiro mês do ano foi designado por Tóon, [29] nome do primeiro criador da Medicina entre este povo.

Em sintonia com esta veneração, a doutrina dos Hebreus ordena que se honre o médico, porque foi o Altíssimo que, por força da lei natural, o criou. ${ }^{117}$ Com efeito, se Deus Óptimo Máximo é o autor da saúde e a natureza o Seu instrumento, o médico é incontestavelmente o ministro de uma e de Outro. ${ }^{118}$

Sócrates, falando da Medicina, afirma que é a única das ciências que tendem para o bem e vemos que não só os maiores filósofos, como até os maiores reis se dedicaram a ela.

Assim, o famoso Hermes, rei dos Egípcios, além de querer ser excelente por aquelas virtudes que convêm a um rei, quis também ser admirado pelo estudo da Medicina. Vejo que o célebre Mitridates, rei dos Persas, fez o mesmo.

$\mathrm{Na}$ verdade, aquele que despreza o médico despreza o segundo autor da vida depois de Deus, e necessariamente se confessa inimigo da luz e da vida.

Se os antigos tanto louvaram a Medicina, que somente diz respeito ao corpo, quanto mais justo é que admiremos e honremos aquelas ciências que estudam e aprofundam o conhecimento não do corpo, mas da própria alma!

Elas são, sem dúvida, tanto mais excelentes, quanto a alma é mais divina que o corpo. E nem só nós, os Cristãos, cremos na sua eternidade e imortalidade: Ferecides 
discipulum Pythagoram confirmasse, Platonemque illum non solum approbasse, sed etiam rationem afferre [30] conatum fuisse.

Iuris Circa igitur animi ipsius dispositionem, ordinationemque primo Iuris prudentiam uersantem uideo. Cuius tanta est maiestas tantaque amplitudo, ut de ea dicturus, initium quidem uideam, exitum certe nesciam qualem mea sit habitura oratio. Nam cuius aut ingenii, aut eloquentiae erit, legis diuinitatem circa quam tota Iuris prudentia uersatur, non dico laudare, sed uerbis tantum explicare?

Quam cum Socrates ille admiraretur, quid amplius diceret, non habuit, nisi legem ipsam, ueritatis certam quandam esse inuentionem. Atque ideo lex sapientissimorum hominum sententia nihil aliud est, quam aeternum quiddam, quod uniuersum mundum regit imperandi prohibendique sapientiam continens. Eamque principem legem mentem esse ducebant omnia pro ratione cogentis, aut uetantis Dei. Quod cum satis intelligeret Chrysippus ille stoicae sapientiae facile princeps, legem humanarum omnium diuinarumque rerum principem et reginam constituebat. Eamque Demosthenes ille cum propter multa alia, tum maxime quia munus donumque Dei esset, uenerandam existimabat. Hanc Pindarus hominum diuumque reginam appellat; et certe non immerito. Nam sine hac, quid sanctum, quid religiosum esset, quod non hominum amentia et temeritas uiolaret? Sine hac quomodo pietas, quomodo religio, quomodo excellens aliqua [31] Respublica posset consistere?

Qua cum nihil, quod quidem in terris fiat, gratius aut acceptius principi illi Deo sit, legem hominibus dedit, qua intelligerent quid illis esset natura concessum, quae esset hominum inter se coniunctio, quae naturalis societas. Sine lege igitur omnia haec, non secus quam corpus sine animo, corruant ac dilabantur, est necesse.

Quod ne fieret statim, ut inquit ille:

Cum prorepserunt primis animalia terris,

Mutum et turpe pecus, [.............]

Oppida coeperunt munire et ponere leges,

Neu quis fur esset, neu latro, neu quis adulter.

Legis igitur excellentiam cum primi illi homines uiderent, et utilitatem sentirent, tantarum rerum auctores non homines, sed deos esse existimarunt. Vnde Aegyptiis Mercurium, Atheniensibus Mineruam, Carthaginensibus Saturnum, Siculis Apollinem, Romanis Egeriam nympham leges tradidisse creditum est.

At uero legum fontes ac capita una Iuris prudentia uidet et interpretatur. Quam si quis contempletur uidebit eam omnem aliam quamuis gloriosam philosophiam facile superare.

Siquidem in hac non opinionibus infinitis, non concertationum plenis disputationibus, sed auctoritate nutuque legum docemur, domitas habere libidines, coercere cupiditates, nostra tueri, ab alienis mentes, oculos, 
de Siro foi o primeiro a afirmá-lo; Pitágoras, seu discípulo, o confirmou, e o sublime Platão não só o aprovou, como procurou alegar [30] uma explicação. ${ }^{119}$

Ocupar-me-ei, em primeiro lugar, da Jurisprudência, que versa a disposição e ordenação do próprio espírito. É tal a sua majestade e grandeza, que, para falar dela, vejo o começo, mas ignoro como terminará a minha exposição.

Pois, de que engenho ou eloquência será próprio, não digo louvar, mas somente explicar por palavras, a sublimidade da lei, de que trata toda a Jurisprudência?

O grande Sócrates, que tanto a admirava, outra coisa não teve a dizer mais senão que a própria lei é uma descoberta segura da verdade. Por conseguinte, a lei, sentença de homens sapientíssimos, não é mais do que algo de eterno que, contendo a sabedoria daquilo que deve ordenar e proibir, rege o mundo em universal. E esses sábios formulavam que a primeira lei é o pensamento de Deus, que tudo obriga ou proíbe segundo a razão. ${ }^{120}$

Crisipo, sem contradito o chefe da sabedoria estóica, porque compreendia suficientemente esta questão, constituiu a lei como a primeira e rainha de todas as coisas humanas e divinas. O notável Demóstenes considerava que ela devia ser venerada por muitas e várias razões, mas sobretudo porque era uma mercê e um dom de Deus. ${ }^{121}$ Píndaro chama-a rainha dos homens e dos deuses; ${ }^{122}$ e não imerecidamente, pois, sem ela, que haveria de sagrado e religioso que a loucura e temeridade dos homens não violasse? Sem ela, como poderia subsistir a virtude, a religião ou algum [31] Estado excelente?

Como nada que existe na terra é mais querido e agradável a Deus soberano do que a lei, deu-a Ele aos homens, pela qual compreendessem o que lhes fora concedido pela natureza, qual a relação dos homens entre si, qual a sociedade natural. ${ }^{123} \mathrm{Na}$ verdade, forçoso é que, sem a lei, todos estes atributos, não menos que o corpo sem alma, desabem e se dissipem.

Para que isto não sucedesse permanentemente, como diz o famoso poeta:

Quando da primitiva terra saíram, rastejando, os seres vivos, gado mudo e horrendo, [...... começaram a construir fortalezas e a decretar leis, para que ninguém fosse salteador, ladrão ou adúltero. ${ }^{124}$

Com efeito, como os homens primeiros vissem a excelência da lei e sentissem a sua utilidade, julgaram autores de tão grandes coisas não os homens, mas os deuses. Daí, que se tenha acreditado que Mercúrio transmitiu as leis aos Egípcios, Minerva aos Atenienses, Saturno aos Cartagineses, Apolo aos Sículos e a ninfa Egéria aos Romanos. ${ }^{125}$

Ora, só a Jurisprudência vê e interpreta as causas e as origens das leis. Se alguém a considerar, verá que ela facilmente supera toda e qualquer filosofia, por mais gloriosa que seja.

Nela somos ensinados, não por opiniões indefinidas, não por discussões cheias de controvérsia, mas por autoridade e imperativo das leis, a dominar as paixões, refrear as cobiças, velar pelos nossos bens e afastar dos bens alheios o nosso 
manus [32] abstinere. Haec una et iure cauere, et consilio iuuare, et scientia prodesse potest. Huius interpretationi cum summa antiquitatis cognitione mira quaedam suauitas et delectatio coniuncta est.

Hac ad senectutem ornandam et celebrandam nullum potest esse honestius perfugium, haec non solum nos sed et domos nostras potest a solitudine uindicare, potestque Iurisconsulti domus uelut totius ciuitatis oraculum illud usurpare, quod apud Ennium de se Apollo Pythius dicebat:

"Omnes mei ciues consilium a me expetunt,

Suarum rerum incerti, quos ego mea ope,

Ex incertis certos, compotesque consili

Dimitto, ut ne res temere tractent turbidas."

Vnde quis non uidet quam sint contemnendae imperitae multitudinis uoces, Iuris prudentiam uelut turbulentam ac litigiosam condemnantes, quae cum dicunt, alterum horum euadere certe non possunt: aut se totius rationis humanaeque societatis hostes esse, aut in iuris ignoratione, quae litigiosa est, penitus uersari.

Quae omnia tanto magis Iurisconsulti omnes suo quodam iure contemnent, quanto magis, quibus eos uerbis Apollo ille Pythius Lycurgi nomine salutet, inspexerint. Sic enim ait:

Te mea conspicio uenientem in templa, Lycurge,

Quem chorus omnis amat Diuum, quem Iuppiter ipse;

Sis ne Deus dubito, uel sis mortalis habendus,

Sed potius te spero Deum numenque, Lycurge.

[33] Haec omnia, quamuis maxima sint, tamen nescio quid maius ac diuinius hominum animus, praesertim Christianus, requirit, quod ipsum plane perficiat, et in quo possit omnino conquiescere.

Id autem unum est sacrosancta illa Theologia, de qua acturus, uideo multo maiora mihi necessario praetermittenda, quam dicenda esse. Nec quidquam plane dicerem nisi Dei Optimi Maximi, cuius hoc totum munus est, auxilio confisus. Qui et mutas hominum linguas in suauissimum sermonem et eloquium soluere est solitus.

Theologiam cum dico, ne me quisquam illam philosophorum, seu potius febricitantium hominum de diis commentationem, quam illi nimis temerarie Theologiam uocarunt, dicere existimet. Sed eam, cuius ne umbram quidem illi unquam uiderunt.

Per quam Deum Optimum Maximum et uitae et huius uniuersi, quod oculis cernitur, auctorem perfecte cognoscimus. In qua sola est sapientia; siquidem Deus ipse sapientia est et lux immensa, quae uniuersa iluminat. Quae certe lux ad nostram usque intelligentiam participationemque se transfundit, et reuelationibus et diuinis demonstrationibus, et mystica sacri eloquii enarratione, iisdemque gradibus humana mens ad suprema conscendit. 
pensamento, [32] olhos e mãos. ${ }^{126}$ Só ela pode acautelar pelo direito, ajudar pela deliberação e ser útil pela ciência.

Uma admirável suavidade e deleite foram acrescentados à sua interpretação, com o conhecimento profundo da Antiguidade. ${ }^{127}$

Não pode haver nenhum recurso mais nobre para exaltar e honrar a velhice do que esta ciência; ela pode defender-nos da solidão a nós e nossas casas. A casa do Jurisconsulto - que é como um oráculo de toda a cidade - pode fazer uso daquelas palavras que, segundo Énio, Apolo Pítio dizia a respeito de si mesmo:

"Todos os meus cidadãos, me pedem conselho, indecisos da sua sorte, e eu, mercê do meu poder, de irresolutos que eram, despeço-os determinados e senhores das suas deliberações, para que não pratiquem, temerariamente, acções violentas.»128

Por conseguinte, quem não verá como devem desprezar-se as vozes insensatas da multidão, que condenam a Jurisprudência como turbulenta e litigiosa? Quando falam, por certo não podem evitar uma destas posições: ou são inimigas de toda a regra e sociedade civilizada, ou encontram-se numa profunda ignorância do direito, que é litigiosa. ${ }^{129}$

Todos os Jurisconsultos, por direito próprio, tanto mais desprezarão todas estas opiniões, quanto mais repararem nas palavras com que o divino Apolo Pítio os saúda na pessoa de Licurgo. Diz assim:

Licurgo, vejo que vens aos meus templos.

Todo o coro dos deuses te ama, até o próprio Júpiter.

Não sei se deves ser considerado deus, se mortal,

mas, ó Licurgo, de ti espero antes um deus ou um nume. ${ }^{130}$

[33] Se bem que todos estas ciências sejam da máxima importância, não sei, todavia, que de maior e mais divino busque o espírito humano, sobretudo o cristão, que o realize plenamente e em que possa descansar em absoluto.

Isso, só a sacrossanta Teologia. E para falar acerca dela, vejo que necessariamente terei de omitir muito mais coisas do que dizer. E nada diria, se não confiasse no auxílio de Deus Óptimo Máximo, a Quem pertence inteiramente esta dádiva. Ele costuma soltar a língua muda dos homens para um suavíssimo diálogo e conversação.

Quando falo em Teologia, ninguém julgue que me refiro à dos filósofos, ou antes, à dissertação de homens exaltados acerca dos deuses, à qual com demasiada temeridade chamaram Teologia. Dela esses nunca viram sequer a sombra!

Pela Teologia conhecemos perfeitamente Deus Óptimo Máximo, autor da vida e deste universo que se estende a nossos olhos. Só nela se encontra a sabedoria: o próprio Deus é sabedoria e luz imensa que ilumina todo o universo. Esta luz difunde-se até à nossa inteligência e participação, não só pelas revelações, demonstrações divinas, como também pela narração mística da Palavra Sagrada. Através destes mesmos degraus o pensamento humano eleva-se para o Alto. De 
Nam sacra diuini eloquii inspectione, caelestia secreta cognoscens, in eorum quae non uidentur, cognitionem succedens, in ipsius tandem diuini numinis et [34] splendoris contemplatione conquiescit.

Circa hanc diuinam sapientiam summi illi philosophi densa obuoluti caligine uersabantur, nec unquam quid uerum esset intelligere potuerunt.

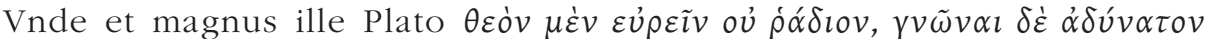
esse affirmauit.

Huius cum se Socrates ille plane expertem uideret, ceteraque omnia nil in se certi aut ueri continere conspiceret, doctrinam non dissimulauit, sed se nil plane scire, nec ullam esse humanam sapientiam professus est. Quin et rex ille Ptolemaeus Theologiam ne attingendam quidem putauit, quod illam admirabili rerum excellentia insignem, humana imbecillitas comprehendere non posset. Nec certe mirum. Natura enim ipsa, cuius ipsi se professores esse dicebant, auctorem creatoremque suum praedicare, illuminare certe eorum animos non potuit.

Totum enim hoc munus, illius rerum omnium conditoris ac parentis est, qui oculis non uidetur et mente uix concipitur. Qui sola sapientia est, et cui ueritas patet uniuersa.

O excellentem sapientiam, quae nobis uitae auctorem demonstrat; o diuinam Theologiam, qua una uel decrepita anicula instructa philosophorum omnium sapientiam potest superare. Haec prima philosophia est, haec philosophiae summa, haec ueritatis perfectio. Hac et quid unusquisque nostrum sit, perfecte cognoscit, et quantam uim rerum optimarum [35] mens humana contineat, et cuius numeris colendi efficiendique causa nati et in lucem editi simus.

Haec una summum illum libertatis nostrae uindicem Christum docet, hominem Deum, et Deum hominem. At quem hominem? - Quem et nobiscum uersatum et, quae nostra est gloria, cruci affixum praedicamus. Qui nullis incantatis carminibus, nullis ad circumscribendos oculos magicis praestigiis, sed

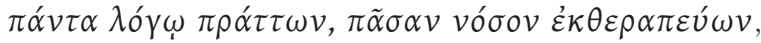

caecis ut uiderent, mortuis ut uiuerent, potuit imperare. Cuius in homines tanta fuit dilectio, tam excellens amor, ut non solum seruare humanum genus, sed et uersari et colloqui nobiscum perpetuo uoluerit. Ministrumque sibi ex hominum genere in terris reliquit, per quem quid ipse uellet cognosceremus, et quem nos imitati ad Deum ipsum maxime accederemus.

Pontifices Hunc ille primo Petrum beatissimum constituit, in cuius postea locum pontifices nostri successerunt. Quorum tanta potestas est, ut nulla secundum Deum in terris sit maior. Quod forte praesagiens multo ante Numa ille Pompilius Romanorum rex, Pontificem primo creauit, cuius potestati non solum omnia sacrorum iura subiecit, sed eum iudicem et arbitrum diuinarum omnium humanarumque rerum constituit. 
facto, conhecendo os segredos celestes pelo estudo sagrado da Palavra Divina, procurando o conhecimento daquilo que está oculto a nossos olhos, a nossa mente repousa, enfim, na contemplação [34] do Seu divino nume e esplendor. ${ }^{131}$

Os maiores filósofos, envoltos em densa bruma, tentavam estudar esta divina sabedoria, mas jamais puderam compreender o que fosse verdadeiro. Daí que o

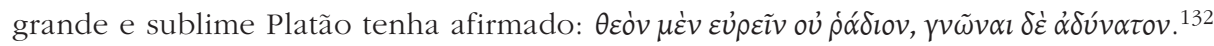

O famoso Sócrates, como se sentisse completamente afastado deste conhecimento e verificasse que tudo o resto não contém em si nada de certo ou verdadeiro, não dissimulou a sua cultura, mas confessou abertamente que nada sabia e que a sabedoria humana era nula. Mais ainda: o rei Ptolomeu considerava que a Teologia nem sequer devia ser abordada, porque a debilidade do espírito humano não tinha capacidade para abranger esta insigne ciência, devido à admirável excelência das questões. ${ }^{133} \mathrm{Nem}$ isso é de admirar, pois a própria natureza, da qual esses mesmos filósofos se diziam cultores, não pôde proclamar o seu autor e criador ou iluminar os espíritos deles.

Com efeito, este é um dom total do criador e pai de todas as coisas, o qual não se vê com os olhos e dificilmente se apercebe pela razão. Ele é a única sabedoria e n'Ele se manifesta a verdade universal.

Ó excelente sabedoria, que nos revelas o autor da vida! Ó divina Teologia, só tu, qual velhinha idosa e instruída, ${ }^{134}$ podes superar a sabedoria de todos os filósofos! Esta é a primeira filosofia; esta é o ponto supremo da filosofia; esta, a perfeição da verdade! Por ela, cada um de nós conhece perfeitamente aquilo que é, quanta abundância de qualidades excelentes [35] encerra a mente humana e ainda para que missão e obra nascemos e viemos à luz. ${ }^{135}$

Só a Teologia ensina Cristo, supremo defensor da nossa liberdade, Homem-Deus e Deus-Homem. Mas que Homem? Aquele que apregoamos ter vivido entre nós e - triste glória a nossa! - ter sido por nós crucificado. ${ }^{136}$

Ele pôde imperar, servindo-se não de mágicas palavras ou mágicos prodígios para iludir os olhos, mas

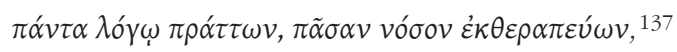

para que, pelos cegos, os homens vissem e, pelos mortos, vivessem.

Tão grande foi a Sua dedicação aos homens e tão sublime o Seu amor, que quis não só salvar o género humano, mas viver e dialogar perpetuamente connosco. Deixou, por isso, na terra, dentre a raça humana, um ministro Seu, através do qual conhecêssemos o que Ele quer e, imitando-o, chegássemos o mais possível até ao próprio Deus.

Instituiu primeiramente S. Pedro, em cujo lugar sucederam depois os nossos Pontífices. Tão grande é a autoridade deles que, depois de Deus, não há maior na terra. Pressentindo-a, casualmente, muito antes o célebre Numa Pompílio, rei dos Romanos, criou pela primeira vez um Pontífice, a cujo poder sujeitou todos os direitos sagrados, tendo-o instituído ainda juiz e árbitro de todas as coisas divinas e humanas. ${ }^{138}$ 
Quae potestas tanto in nostris Pontificibus est excellentior, quanto magis est ab illorum hominum erroribus [36] et tenebris aliena.

Ex hisce fontibus manat, pleno iam alueo, aureum illud flumen excellentem sapientiam continens, quam nos Pontificiam appellamus. De qua dicturus, optarem illud eloquentia posse efficere, quod olim aiunt excellentem illum Phidiam arte praestitisse. Qui Mineruam Athenis, Iouem in Elide Olympium ita dicitur effinxisse, ut eorum pulchritudo aliquid etiam adderet receptae hominum religioni.

Verum iuris pontificii sapientia tam excellens est, tam hominum saluti necessaria, ut ineptus sit qui illam eloquentia posse magis commendari existimet.

Haec siquidem et abdita illa sacramentorum Scripturarumque mysteria interpretatur, et ad hanc unam, ubi quid ambiguum inciderit, recurrendum est. Qua una sublata uidemus non religionem, non fidem, non caritatem, non pietatem denique posse consistere. Haec est animi peccantis medicina, haec recti atque integri conseruatrix; ad hanc confugiat est necesse qui nec peccantem impunitum, nec paenitentem sine miseratione relictum esse crediderit.

Huius contemptores expectant illa,

\section{Acherontia templa, alta Orci, pallida}

Leti, obnubila, obsita tenebris loca.

Audiuistis, auditores studiosissimi, doctrinarum scientiarumque omnium excellentiam.

Quae omnia nescio [37] qua temporum iniuria, et hominum ignauia, seu potius amentia, in nostra Lusitania sepulta erant; apud quos scelesta ea persuasio inualuerat ut non modo haec nescire, sed primas etiam litteras ignorare esset ualde gloriosum.

Ioannes tertius

Rex Lusitaniae

Perdurauitque haec hominum barbaries, donec Dei Optimi Maximi munere nostrae Lusitaniae rex est concessus Ioannes, nomine quidem tertius, regum uero omnium facile princeps; quem, ut Ennius Romulum, sic nos alloqui licet,

[................] O Maxime, Maxime die, o

Qualem te patriae custodem di genuerunt;

Tu produxisti nos intra luminis oras.

O pater, o genitor, o sanguen dis oriundum.

De quo id dicere satis est, Rege Ioanne nec religiosiorem, nec sapientiorem, nec inuictum magis exteras nationes non modo non uidisse, sed nec optando, aut cogitando consequi potuisse.

Cuius ut imperium iisdem finibus, quibus et terrarum orbis terminatum, ut excellentes ac magnificos ab extremis usque Indis partos triumphos praetermittam; illud certe praetermittere non possum, quod omnibus his contemptis, aliunde gloriam multo solidiorem sibi existimauit comparandam. Voluitque uniuersam suam Lusitaniam quemadmodum ab hostibus, ita etiam 
É tanto mais excelente o poder dos nossos Pontífices, quanto mais alheio é aos erros [36] e trevas desses homens.

Destas fontes, corre, já em pleno leito, aquele rio áureo que contém uma elevada sabedoria, a que chamamos Pontifícia.

Direito

Para discorrer sobre ela, eu desejaria poder realizar, com a eloquência, aquilo que, segundo dizem, outrora o excelente e sublime Fídias realizou com a arte. Diz-se que esculpiu Minerva em Atenas e Júpiter Olímpico na Élide, de tal maneira, que a beleza destas esculturas acrescentou algo mais à religião que os homens do tempo professavam. ${ }^{139}$

Mas a sabedoria do Direito Pontifício é tão notável, tão necessária à salvação dos homens, que é inepto quem julgue poder exaltá-la mais pela eloquência.

Ela interpreta os mistérios ocultos dos sacramentos e das Escrituras e só a ela se deve recorrer quando surge algo de ambíguo. Uma vez suprimida, verificamos que nem a religião, nem a fé, a caridade, nem, enfim, a piedade, podem subsistir. Ela é o remédio da alma pecante, ${ }^{140}$ a defensora da rectidão e da integridade. Nela se refugia necessariamente aquele que acreditar que não fica impune quando peca, nem abandonado sem misericórdia quando se arrepende.

Os que desprezam a Teologia esperam

As regiões infernais do Aqueronte, as margens do Orco,

lugares pálidos, sombrios e tenebrosos do Letes. ${ }^{141}$

Doutíssimos ouvintes, acabais de ouvir a excelência de todas as doutrinas e ciências.

E não sei [37] por que injúria dos tempos, por que ignávia dos homens ou, antes, por que demência, tudo isto esteve adormecido na nossa Lusitânia. Entre nós prevalecia a maldita convicção de que era deveras glorioso não só desconhecer estas coisas, como até ignorar as primeiras letras.

E esta incultura dos homens perdurou até que, por graça de Deus Óptimo Máximo, foi concedido à nossa Lusitânia o Rei D. João, terceiro de seu nome, sem contradito o príncipe de todos os reis, ${ }^{142}$ a quem, como Énio a Rómulo, nos é lícito dirigir assim:

D. João III, rei da Lusitânia

[.................... Ó Supremo, sumamente divino,

Os deuses te geraram guardião da pátria!

Tu nos conduziste para dentro das margens da luz!

Ó Pai! Ó Criador! Ó sangue oriundo de deuses! 143

A respeito deste soberano, basta dizer que as nações estrangeiras não viram ninguém mais religioso, mais sábio ou mais invicto que o Rei D. João, nem sequer conseguiram igualá-lo, conquanto o desejassem ou nisso colocassem seu pensamento. ${ }^{144}$

Ainda que não me refira ao seu império, delimitado pelas mesmas fronteiras da terra, ainda que omita as notáveis e magníficas vitórias alcançadas desde os confins das Índias, um facto, todavia, não posso omitir: que, menosprezados todos estes aspectos, considerou que devia obter para si, de outra parte, uma glória muito mais sólida. Assim, quis que toda a sua Lusitânia fosse liberta de toda a espécie de 
ab omni barbarie liberatam. Quod ut efficeret, Academiam hanc uniuersi terrarum orbis florentissimam constituit; [38] eique rectorem ac moderatorem

Iacobus a Murcia Rector uigilantissimum praefecit Iacobum a Murcia, non solum uitae sanctimonia imitandum, sed et sacrosanctae Theologiae singulari cognitione suspiciendum. De cuius integritate, prudentia, humanitate aliquid dicerem, nisi praesentem uiderem.

Addidit et doctores in omni doctrinarum genere selectissimos, quos amplissimis propositis muneribus ex uniuerso terrarum orbe in suam Conimbricam Academiam conuocauit. De quibus quanto magis conor aliquid dicere, tanto me magis Homericus ille uersiculus,

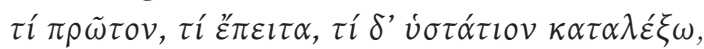

admonet, non cuiusuis id ingenii esse. Praestantibus enim in rebus cum primum facile inuenias, quid secundum dicas, semper fuit difficilimum inuenire.

Regi igitur et fortissimo et inuictissimo, et patriae doctrinarumque omnium parenti bene precemur:

Viue igitur felix, multos uicturus in annos, Maxime Rex Regum, caelo quem Iuppiter alto, Hesperiam ut regeres, misit, pontoque superbo Iura dares; sceptroque tuo subiecta manerent, Exoriens quaecunque uidet sol aureus orbis, Occiduus quaecunque etiam post terga relinquit.

Te tumidi Persae regem dominumque fatentur, Teque Arabes posito ferro uenerantur, et arcu. Antebac non Indus bello seruire coactus Imperium nomenque tuum miratur, et ultro

[39] Iam sequitur, laudatque tuos spectatque triumphos. Viue diu, populumque tuum ne sperne uocantem Te regem, dominumque pium, patriaeque parentem.

Nunc uestrum erit, auditores humanissimi, sic istius anni curriculum et incipere et perficere, ut uobis minime defuisse uideamini. Quod diligentius facietis, si iam Homerum illum clamantem audiueritis: O homines, sit uobis cura sapientiae, quae et cum naufrago simul enatat, et in litore nudum eiectumque fortunatis Phaeacibus ostendit multo uenerabiliorem.

Et certe ita res est. Nam cetera non magis possidentium sunt, quam cuiusque. Sola sapientia stabilis est, et mortuo et uiuo firma possessio.

DIXI. 
ignorância, como o foi dos inimigos. E para o realizar, instituiu esta Academia, a mais florescente de toda a terra $;^{145}[\mathbf{3 8}$ ] e confiou-a a Diogo de Murça, reitor e moderador vigilantíssimo, que deve ser não só imitado pela rectidão da sua vida, como admirado pelo conhecimento singular da Teologia Sagrada. Algo diria acerca da sua integridade, prudência, humanidade, se o não vira aqui presente. ${ }^{146}$

Aumentou o número dos mestres, muito distintos em todos os campos do saber, os quais chamou de toda a parte do mundo para a sua Academia de Coimbra, propondo-lhes os mais amplos benefícios. ${ }^{147} \mathrm{E}$ quanto mais me esforço por algo dizer a respeito deles, tanto mais aquele verso de Homero,

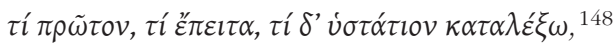

me adverte de que fazê-lo não é próprio de um qualquer engenho. Com efeito, quando se trata de factos notáveis, facilmente se encontra o que dizer em primeiro lugar, mas sempre foi muito difícil encontrar o que dizer em segundo lugar.

Ao mui valoroso e invictíssimo Rei, pai da Pátria e de todos os ramos do saber, façamos, pois, este augúrio:

Vive, pois, feliz, vivendo por muitos anos,

Máximo Rei dos Reis, a quem Júpiter lá do alto céu

Enviou, para que governasses a Hespéria e ditasses as leis

Sobre o soberbo mar; e para que permanecesse, sujeito ao teu ceptro,

Tudo o que da Terra o áureo Sol nascente vê

E tudo o que, ao pôr-se, deixa atrás de si!

Que os soberbos Persas te reconheçam Rei e Senhor!

Que os Árabes te venerem, pousadas as armas e os arcos!

Dantes, o Indiano, forçado a entregar-se à guerra,

Não admira o teu poder e fama. Agora, espontaneamente,

[39] Já segue, louva e contempla com respeito os teus triunfos!

Vive por muito tempo e não desprezes o teu povo

Que te proclama Rei e Senhor piedoso e Pai da Pátria! 149

Agora a vós pertencerá, ilustríssimos ouvintes, iniciar e concluir o curso deste ano com uma perfeição que parece não vos faltar de todo. E fá-lo-eis com mais diligência, se doravante ouvirdes o famoso Homero clamando: Ó homens, haja em vós o cuidado da sabedoria, a qual não só se salva juntamente com o náufrago, mas ainda - a ele, desnudo e arremessado à praia - o mostra aos afortunados Feaces muito mais digno de veneração.

Assim é, sem dúvida. O resto não pertence mais aos que o possuem do que a cada um. Só a sabedoria é estável, firme riqueza que se leva ao morrer e que se mantém enquanto se vive.

DISSE. 